\title{
New High-Tech Flexible Networks for the Monitoring of Deep-Sea Ecosystems
}

Jacopo Aguzzi, ${ }^{*} \dagger \odot$ Damianos Chatzievangelou, ${ }^{\ddagger}$ Simone Marini, ${ }^{\S}$ Emanuela Fanelli, ${ }^{\|}$Roberto Danovaro, ${ }^{\|, \perp}$ Sascha Flögel, ${ }^{\#}$ Nadine Lebris, ${ }^{\nabla}$ Francis Juanes, ${ }^{\bullet}$ Fabio C. De Leo, ${ }^{\bullet, \bigcirc}$ Joaquin Del Rio, ${ }^{, \mathrm{I}}$ Laurenz Thomsen, ${ }^{\ddagger}$ Corrado Costa, ${ }^{\otimes}$ Giorgio Riccobene, ${ }^{\Delta}$ Cristian Tamburini, ${ }^{\Delta}$ Dominique Lefevre, ${ }^{\Delta}$ Carl Gojak, Pierre-Marie Poulain,,${ }^{\diamond}$ Paolo Favali, ${ }^{\ddagger}, \infty$ Annalisa Griffa, ${ }^{\S}$ Autun Purser, $\square$ Danelle Cline, ${ }^{\square}$ Duane Edgington, ${ }^{\square}$ Joan Navarro, ${ }^{\dagger}$ Sergio Stefanni, ${ }^{\perp}$ Steve D'Hondt, ${ }^{\star}$ Imants G. Priede, ${ }^{\hat{\lambda}, @}$ Rodney Rountree, ${ }^{\boldsymbol{Q}, \forall}$ and Joan B. Company ${ }^{\dagger}$

${ }^{\dagger}$ Instituto de Ciencias del Mar (ICM-CSIC), Paseo Marítimo de la Barceloneta, 37-49, 08012 Barcelona, Spain

† Jacobs University, 28759 Bremen, Germany

${ }^{\S}$ Institute of Marine Sciences, National Research Council of Italy (CNR), 19036 La Spezia, Italy

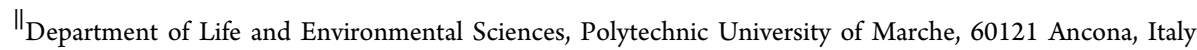

${ }^{\perp}$ Stazione Zoologica Anton Dohrn (SZN), 80121 Naples, Italy

\#GEOMAR, 24148 Kiel, Germany

$\nabla$ Oceanological Observatory, CNRS LECOB, Sorbonne University, 66650 Banyuls-sur-mer, France

Department of Biology, University of Victoria, Victoria, British Columbia V8W 2Y2, Canada

Ocean Networks Canada (ONC), University of Victoria, Victoria, British Columbia V8N 1V8, Canada

II OBSEA, SARTI, Universitat Politècnica de Catalunya (UPC), 08800 Barcelona, Spain

${ }^{\otimes}$ Consiglio per la ricerca in agricoltura e l'analisi dell'economia agraria (CREA-IT), 00198 Monterotondo, Italy

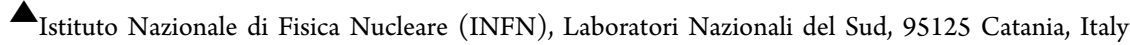

${ }^{\Delta}$ Institut Méditerranéen d'Océanoloie (MIO), 13288 Cedex 09 Marseille, France

$\checkmark$ DT INSU, 83507 La Seyne-sur-Mer, France

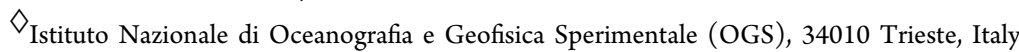

${ }^{£}$ Istituto Nazionale di Geofisica e Vulcanologia (INGV), 00143 Rome, Italy

${ }^{\infty}$ European Multidisciplinary Seafloor and Water-Column Observatory European Research Infrastructure Consortium (EMSO ERIC), 00143 Rome, Italy

Alfred Wegener Institute (AWI). 27515 Bremerhaven, Germany

$\square$ Monterey Bay Aquarium Research Institute (MBARI), Moss Landing, California 95039, United States

* Graduate School of Oceanography, University of Rhode Island, Narragansett, Rhode Island 02882, United States

${ }^{3}$ University of Aberdeen, Aberdeen AB24 3FX, United Kingdom

${ }^{\circledR}$ Hellenic Centre for Marine Research, 71003 Heraklion Crete, Greece

${ }^{\forall}$ The Fish Listener, 23 Joshua Lane, Waquoit, Massachusetts 02536, United States

ABSTRACT: Increasing interest in the acquisition of biotic and abiotic resources from within the deep sea (e.g., fisheries, oil-gas extraction, and mining) urgently imposes the development of novel monitoring technologies, beyond the traditional vessel-assisted, time-consuming, high-cost sampling surveys. The implementation of permanent networks of seabed and water-column-cabled (fixed) and docked mobile platforms is presently enforced, to cooperatively measure biological features and environmental (physicochemical) parameters. Video and acoustic (i.e., optoacoustic) imaging are becoming central approaches for studying benthic fauna (e.g., quantifying species presence, behavior, and trophic continued...

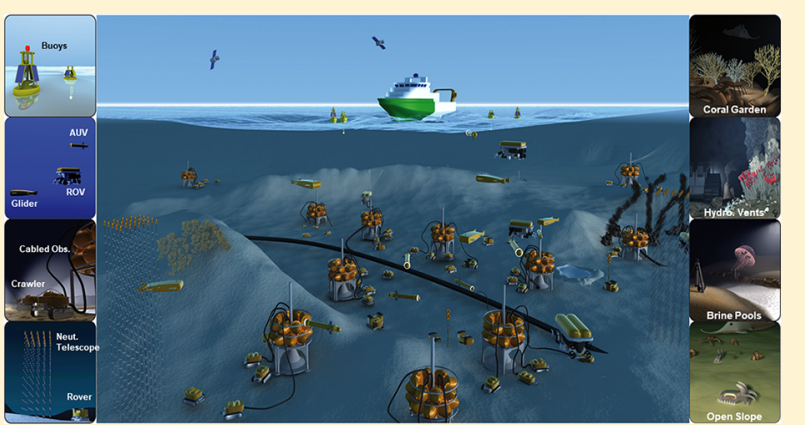

Received: January 19, 2019

Revised: April 23, 2019

Accepted: May 10, 2019

Published: May 10, 2019 
interactions) in a remote, continuous, and prolonged fashion. Imaging is also being complemented by in situ environmentalDNA sequencing technologies, allowing the traceability of a wide range of organisms (including prokaryotes) beyond the reach of optoacoustic tools. Here, we describe the different fixed and mobile platforms of those benthic and pelagic monitoring networks, proposing at the same time an innovative roadmap for the automated computing of hierarchical ecological information on deep-sea ecosystems (i.e., from single species' abundance and life traits to community composition, and overall biodiversity).

\section{INTRODUCTION}

Throughout the Anthropocene $\mathrm{Era}^{1}$ the human footprint on the ecosystems of the global ocean has been increasing continuously. ${ }^{2}$ Since this footprint is rapidly expanding toward great depths, the need for a global observing effort in the deep ocean is crucial. ${ }^{3}$ Accurate monitoring of our incursive impacts on marine ecosystems, however, requires the development of novel and effective technological solutions.

The deep-sea seafloor and overlying waters (below $200 \mathrm{~m}$ depth) form the largest biome on Earth, although it remains poorly explored. ${ }^{4-6}$ The monitoring of key ecosystem features and functions has proven difficult, owing to the extreme environmental conditions associated with these depths (e.g., high pressures, low temperatures, corrosiveness, and remoteness), coupled with limited sampling capabilities offered by low numbers of adequately equipped research vessels. ${ }^{7}$

In order to sustain correct management and protection actions, a spatiotemporally extended monitoring regime must be implemented to gather data on species and their communities across the vast extent of the great global ocean basins. ${ }^{8}$ Clear examples of shortfalls in current data include the lack of knowledge on biomass, abundance, reproductive cycles, population dynamics (i.e., growth and mortality), migrations, and geographic ranges. ${ }^{9}$ Furthermore, community biodiversity, food web structures and the influence of organic matter transfer within ecosystem compartments and across boundaries are also poorly studied in relation to the neighboring shallower and coastal ecosystems. ${ }^{10}$ All these aspects have repercussions on penetration and propagation of the human footprint into marine ecosystems (e.g., pollutants and microplastics ${ }^{11}$ ).

To fill these knowledge gaps, the efficient integration of ongoing technological developments into a strategic framework for deep-sea monitoring is critical (e.g., see ref 12). Such development should be capable of producing tools for the spatiotemporal location and quantification of deep-sea organisms across a wide range of body sizes, as well as their activity and response to changing environmental conditions and anthropogenic stressors.

1.1. Objectives. In this study, we review the status and development of high-tech, interactive networks of fixed and mobile platforms, currently used for spatiotemporally flexible and appropriate monitoring of deep-sea ecosystems. We propose an innovative roadmap for the hierarchical extraction of ecosystem indicators related to assemblage structure, biodiversity, and ecosystem functioning, as obtained from biological variables encompassing species abundances, demographic descriptors, and behavior. We center our analysis on ecosystem indicators extracted from video and acoustic imaging of marine megafauna (i.e., organisms of size from centimeters and above), representing the apical ecological complexity component, that is fundamental in conditioning ecosystem functioning, services, and health. ${ }^{13}$

\section{GROWING HIGH-TECH CABLED OBSERVATORY NETWORKS}

The ongoing technological development in seafloor cabled observatories is motivated by the growing awareness about the strategic value of acquiring multidisciplinary biological and environmental data in a concomitant fashion, in order to derive putative cause-effect relationships as drivers of ecosystem changes. ${ }^{14-16}$ The successful integration of such platforms equipped with camera systems, multiparametric bio-geochemical, oceanographic, and biological sensors with seafloor power and communication cables now allows the remote, continuous, high-frequency ( $>1 \mathrm{~Hz}$ as real time), long-term (up to decades) monitoring of the deep-sea biome. ${ }^{17}$ In this highly integrated monitoring approach, megafauna identification, tracking, and counting through optoacoustic and new molecular sensors should be a key focus, in relation to productivity and services (e.g., fishery ${ }^{18}$ ).

Throughout the past two decades, cabled observatories have provided relevant data, helping to fill the gaps in knowledge on species' presence, behavior, and associated changes in biodiversity and ecosystem function (Table 1). Unfortunately, cabled systems are fixed and have limited spatial coverage when the deep continental margins and ocean basins are considered as a whole. ${ }^{8,18}$ An attempt to overcome such a limitation has occurred in some cases through the installation of a local network of seabed platforms. Good examples are the Ocean Network Canada (ONC), Deep-Ocean Environmental LongTerm Observatory System (DELOS), and Lofoten Verlag Observatory (LoVe) respectively in Juan de Fuca plate (NW Pacific), off Angola (SE Atlantic), and in Norway. ${ }^{19-22}$

The deployment of observatory modules in clusters with separation distances on the order of hundreds of meters or a few kilometres is presently envisaged to maximize the ability to quantify species distributions and habitat associations over multiple scales (see Table 1). Deploying multiple ecosystem observatory clusters along environmental or habitat gradients would be effective in elevating the system from examination of local habitats to ecosystem level observation. Each node can acquire imaging and acoustic as well as multiparametric environmental data in a temporally coordinated fashion. Accordingly, temporal changes in species' presence and abundance in an area of the deep sea can be tracked through neighboring environments. ${ }^{23,24}$

2.1. Increased Spatial Monitoring Capability with Permanent Mobile Platforms. Nevertheless, networks of cabled observatories are not enough to ensure efficient monitoring across highly variable benthic seascapes. ${ }^{18}$ Presently, there is a drive to integrate mobile platforms through docking stations into existing cabled observatory infrastructures, to provide extended coverage at local, regional, and basin-wide spatial scales, both on the seafloor and within the water column (Figure 1). Benthic mobile platforms are represented by crawlers: a new class of internet operated vehicles (IOVs), tethered to cabled observatories. ${ }^{25}$ These tracked vehicles are 


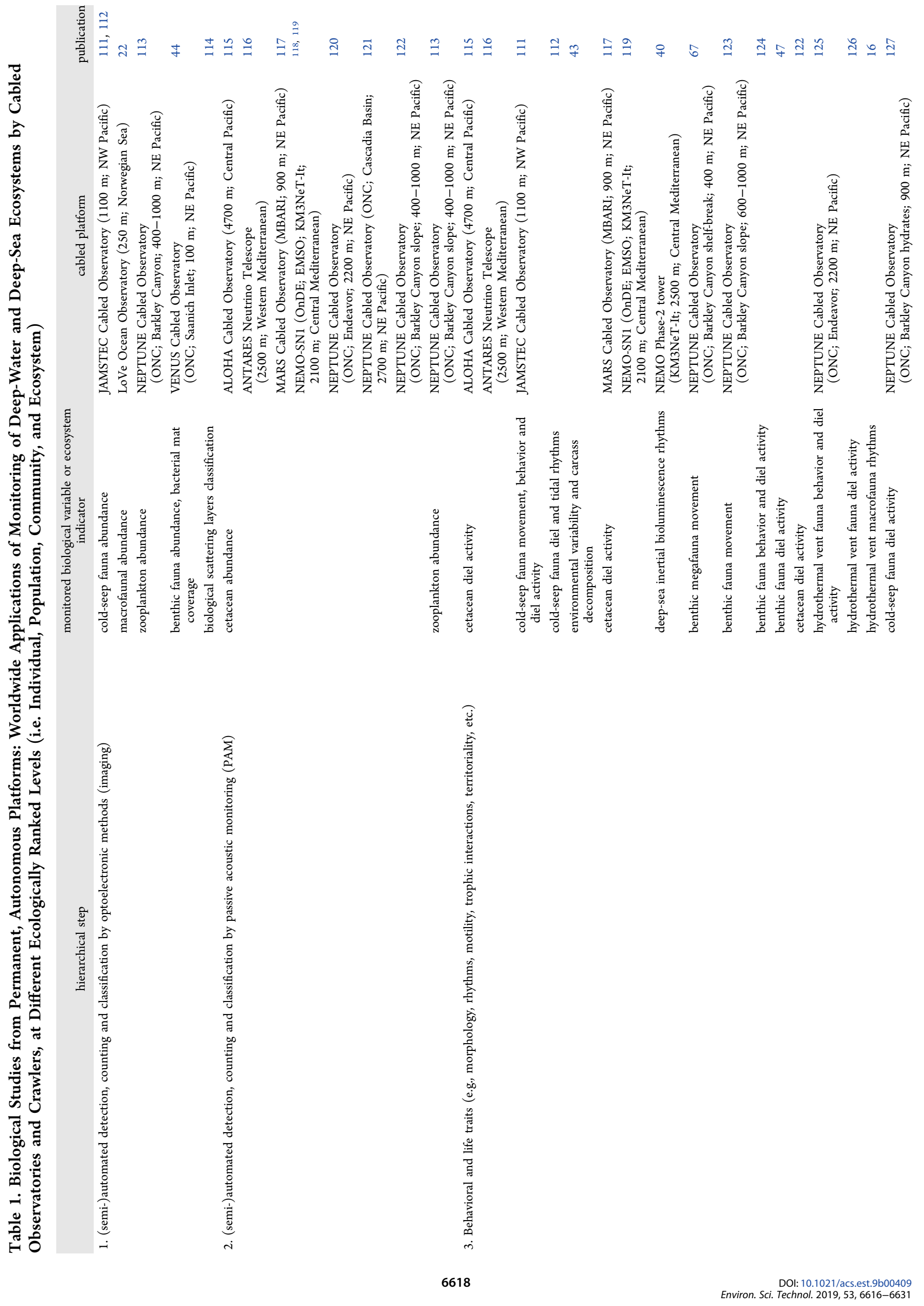




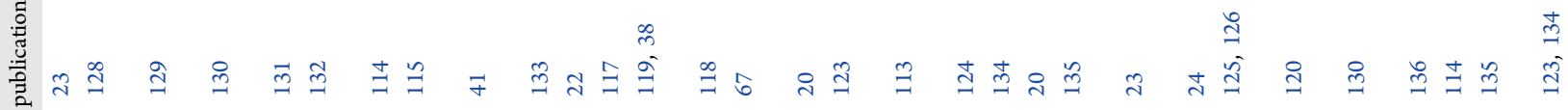
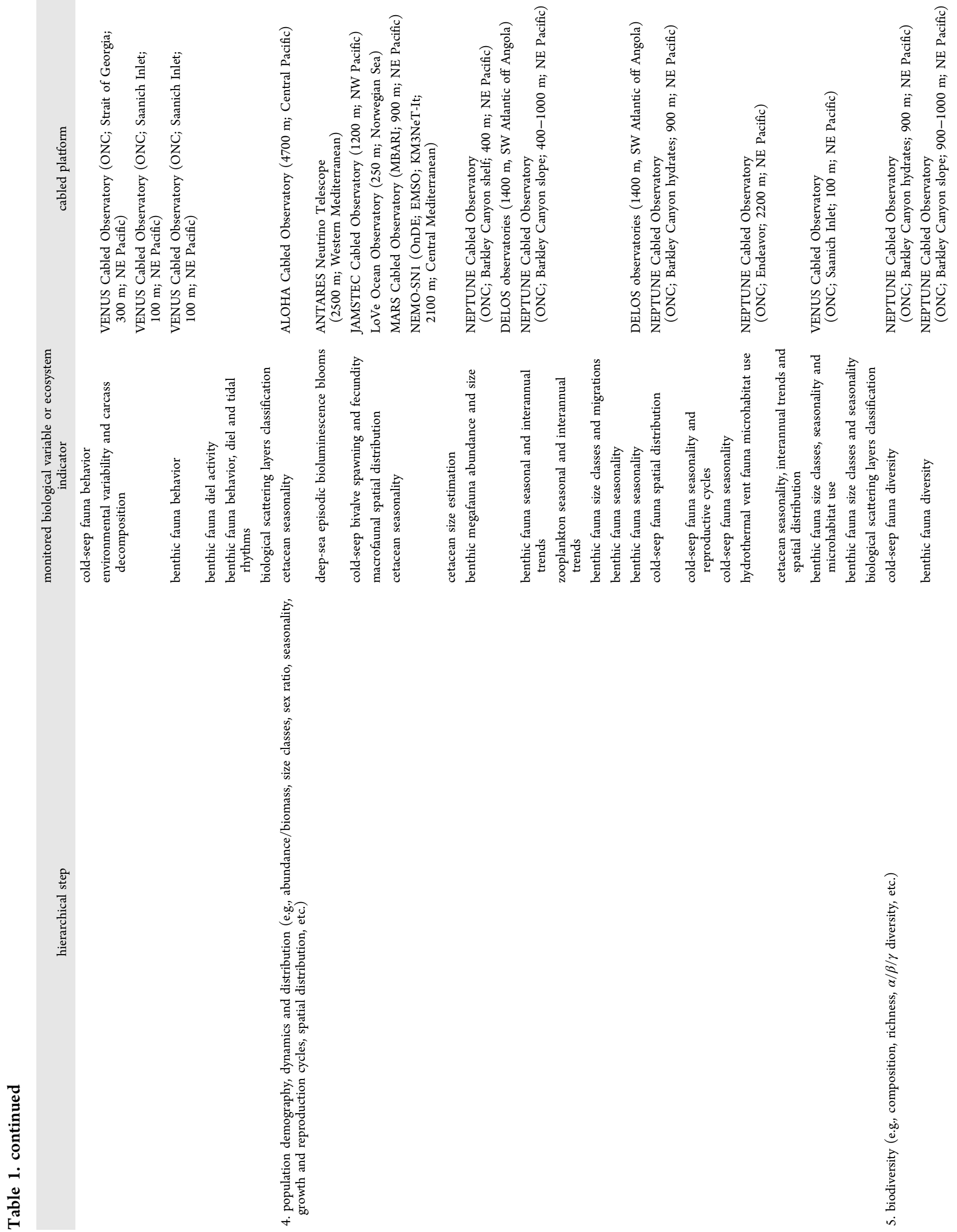

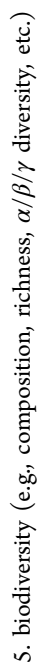




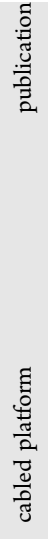

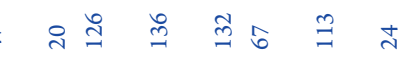
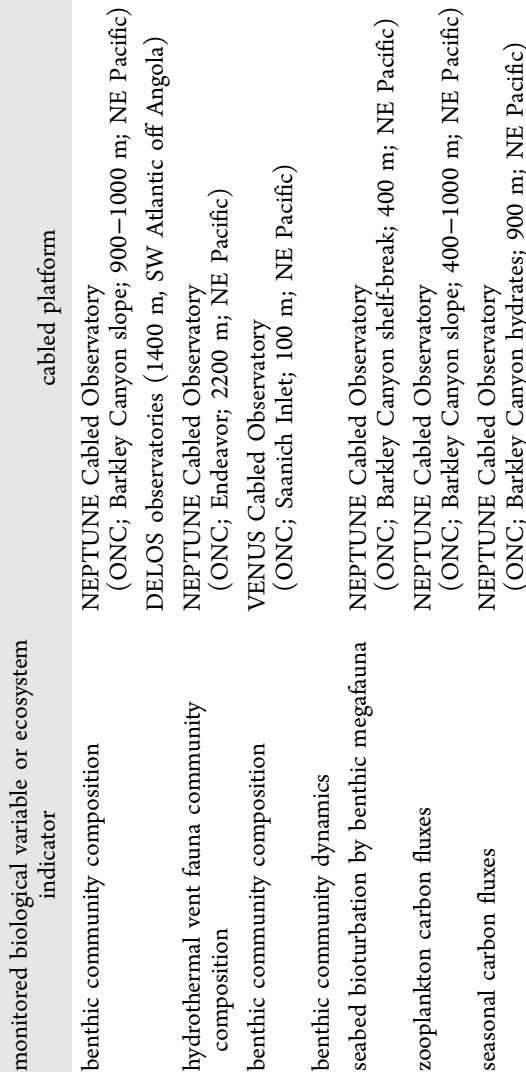

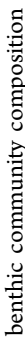

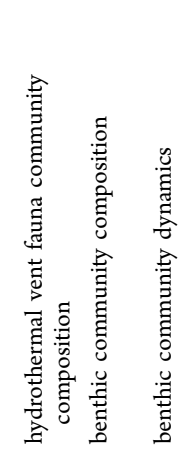

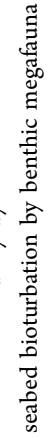

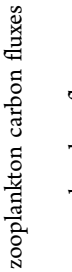

capable of real-time navigation control and data collection via simple web browser interfaces operable from anywhere. At the same time, a new class of rovers, nontethered benthic mobile crawlers, are entering into active research, capable of automatically returning to the docking station for charging, data transfer, or recovery. ${ }^{26}$ To complement the seafloor monitoring capacities of crawler systems, pelagic monitoring is presently achieved using tethered remotely operated vehicles (ROVs) and free swimming autonomous underwater vehicles (AUVs), some of which may also dock with cabled stations for energy recharge and data transmission. ${ }^{27}$ These also allow monitoring of the water column at a high frequency over extended periods and across depth strata. ${ }^{28,29}$

Each of these mobile platforms provides a unique contribution to the ecosystem observatory, as well as some task redundancy. The AUV equipped with imaging or acoustic devices is ideally suited for habitat and biota distribution mapping ${ }^{30,31}$ and can be used to conduct transects around the observatory and between observatories. The AUV provides the highest mobility and flexibility in sampling design for mapping with impacts on the benthic habitat by maritime activities (e.g., noise, substrate disturbance at different scales, and artificial light pollution effects). Although the ROV design implies a tether, such a platform has also a high mobility and it can be used similarly to AUVs, ${ }^{32}$ with the advantage of having two way realtime data transmission and manipulator arms to be used for management and maintenance tasks within the monitoring infrastructure (e.g., manipulative experiments or for placing autonomous recorders such as stand-alone autonomous cameras). In addition, ROVs are the best option for collecting video data on the development of the fouling community on the observatory infrastructure and fauna association with the structure. The major drawback of ROVs is that they must operate with thrusters, creating high levels of noise and their limited ability to conduct sampling and observations at specific locations for extended periods of time. ${ }^{33}$ Crawlers, on the other hand, can be used to conduct census observations at specific locations (in constant transect or stepping-stone fashion) for extended time periods (minutes to hours). Crawlers can also share some infrastructure servicing tasks with the ROVs and carry larger payloads. Drawbacks to crawlers include noise production but, more importantly, physical disturbance of the benthic habitat and associated fauna along the movement tracks.

2.2. Benthic Networks Growing in the Pelagic Realm. The need to monitor energy fluxes between pelagic and benthic ecosystem compartments (i.e., benthopelagic coupling) and their spatiotemporal changes (e.g., ${ }^{34}$ ), requires the development of three-dimensional monitoring networks of platforms, with cabled nodes and mobile platforms operating in tandem (Figure 2). This ecologically integrated monitoring is presently being facilitated by incorporating to the benthic data collection, secondary data streams supplied by fixed (i.e., moored) water column and superficial buoys, as well as satellites. ${ }^{24}$ Satellites are optimal tools for gathering large-scale physicochemical data from superficial (i.e., epipelagic) ecosystems, quantifying relevant biological variables from ocean color (e.g., chlorophyll content, particulate matter, and so on). Unfortunately, satellite sensors cannot penetrate much beyond the surface of a global water mass, and therefore pelagic buoys are more appropriate for the monitoring of subsurface oceanic strata.

In this scenario, benthopelagic monitoring capabilities are also being potentiated via data collection from the routine operations of large astrophysical experimental infrastructures, 


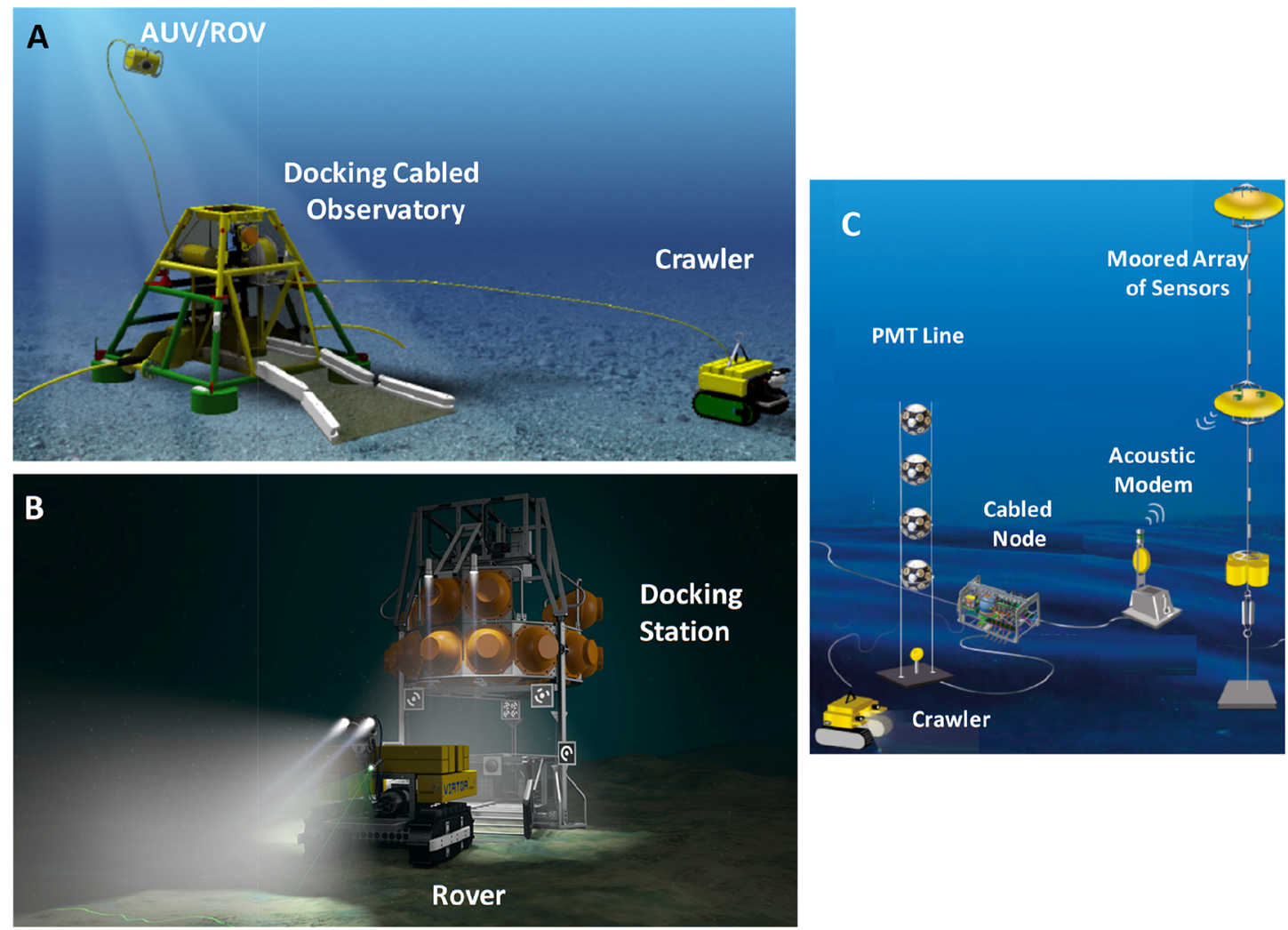

Figure 1. Fixed (i.e., cabled) and mobile docked platforms constituting a spatial network for the integrated benthic and pelagic ecosystem monitoring. (A) Video-cabled multiparametric observatory platform, acting as a docking station for a pelagic remotely operated vehicle (ROV) and a tethered mobile benthic crawler; (B) rover (MANSIO-VIATOR) similar to crawlers but not tethered, docked to a vessel-assisted repositioning station; (C) architecture of ANTARES (the Astronomy with a Neutrino Telescope and Abyss environmental RESearch detector) with a line of photomultiplier tubes (PMTs) and a tethered crawler.

such as underwater neutrino telescopes (see Figure 1C). These telescopes consist of arrays of vertically moored (up to $700 \mathrm{~m}$ ), flexible strings or towers of photon detectors (photomultiplier tubes; PMTs) for neutrino particle quantification, placed at different altitudes above the seabed and connected to shore via power and fiber-optic data cables. ${ }^{35}$

Although the primary use of these platforms is within the high-energy astrophysics domain, ${ }^{36}$ their infrastructure provides a network of subsea connection points and sensors usable for marine ecological monitoring. Hydrophones for passive acoustic listening are connected to the system to monitor the position of the towers in relation to currents and to simultaneously triangulate the PMT location with the aid of acoustic beacons, so that the trajectories of detected neutrinos can be properly computed. As a byproduct, this real-time acoustic monitoring produces useful oceanographic flow condition data and information on anthropogenic marine noise, as well as cetacean movement, population structure, and communication. ${ }^{37-39}$ The PMT detectors themselves also provide unique high-frequency and continuous data on bioluminescence, as swimming animals luminesce when hitting the infrastructures. ${ }^{40}$ At the time of writing, real-time and continuous data acquisition from these telescope infrastructures as a whole is providing important information on seasonal changes in gravity carbon fluxes and controlling oceanographic processes (e.g., dense shelf water cascading and effects on deep-sea bacterial productivity. ${ }^{35,41,42}$

\section{ROADMAP FOR THE MONITORING OF ECOSYSTEM INDICATORS}

The development of efficient deep-sea ecosystem monitoring is currently based on the successful extraction and quantification of key ecosystem characteristics (e.g., biogeochemistry, animal presence, abundance and behavior, local and regional biodiversity, and ecosystem functioning; see Table 1). This monitoring development is being based on the combined use of optoacoustic and molecular biological sensors which are being implemented in the framework of cabled observatories. The capability to acquire a temporally related time series of multiparametric habitat and biological data allows researchers to envision aspects such as benthic primary production via chemosynthesis, deep-sea species ecological niches, and food web structure. ${ }^{43-45}$ These data sets can be used to feed new numerical-based ecology approaches centered on multivariate statistics, time series analysis and ecosystem modeling (e.g., see refs 24 and 46-48), in order to estimate the level of significance for putative cause-effect relationships (i.e., environmental control versus species and communities response) and provide an immediate vision of complex ecological processes at a local scale (e.g., species tolerance to the variation of key habitat drivers). This approach allows a transition from a still too descriptive deep-water and deep-sea ecology into a more quantitative one, as occurs in more directly accessible coastal areas and land.

To optimize the outcome quality from a highly integrated deep-sea monitoring strategy of this type, protocols for data collection and analysis should be implemented to efficiently 


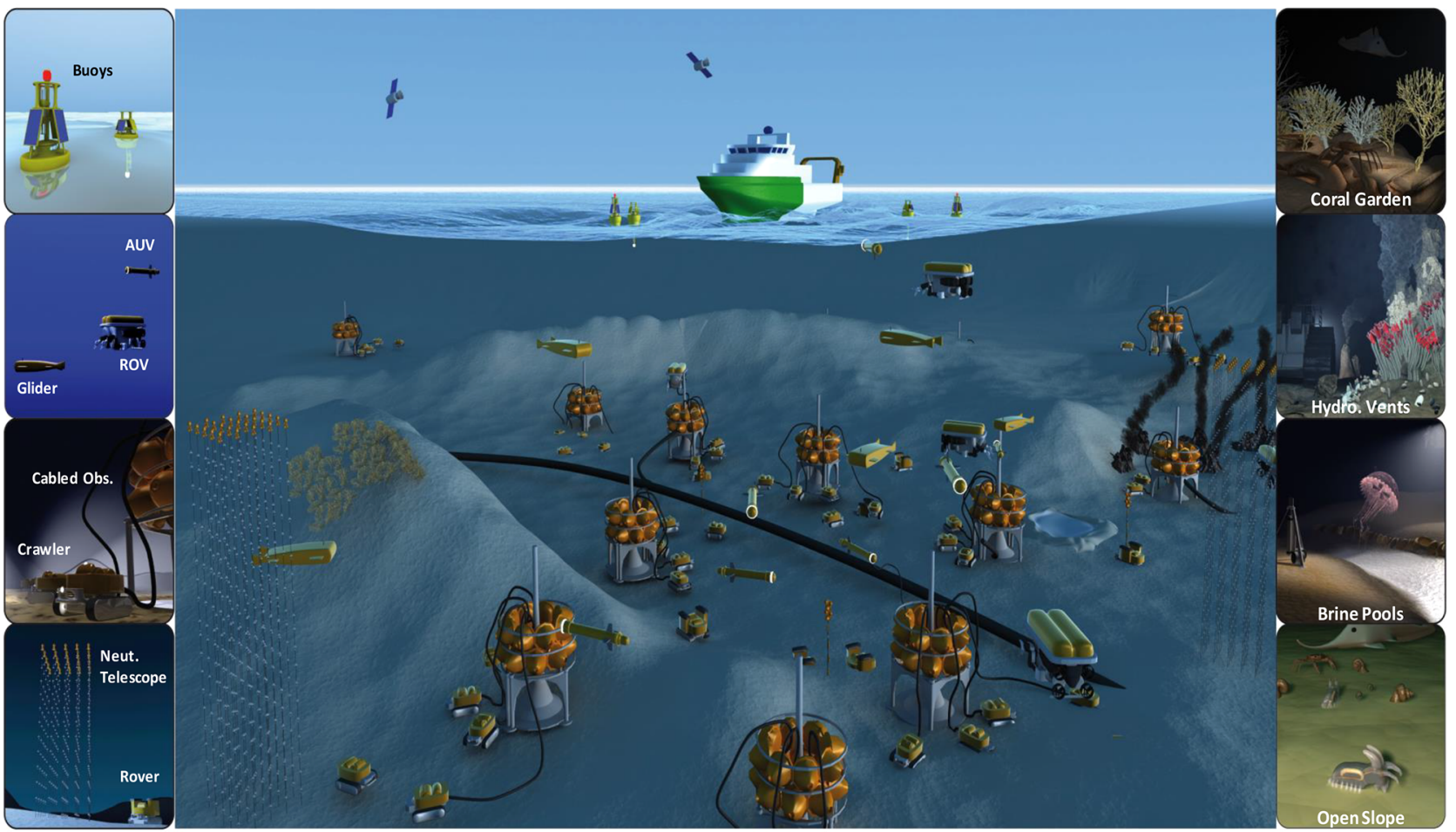

Figure 2. Illustration of a variety of cabled observatories providing the sea bed infrastructure to control and coordinate mobile benthic and pelagic platforms such as docked crawlers, rovers, and AUVs. Platform monitoring is assisted by vessels and satellite-based technologies. Neutrino telescope is an array of vertical moored lines of PMTs deployed in the deep sea. Seabed infrastructures providing power and data transfer may be aided by connection with industrial or telecommunication cables, as reliable low-cost means for network deployment into vast abyssal areas. ${ }^{8}$

characterize local biodiversity along with those processes that sustain it and determine the overall ecosystem functioning and health status. ${ }^{49,50}$ From an operational point of view, a bottomup scheme of monitoring should be conceived with cabled observatories and docked mobile platforms producing video and acoustic imaging information on fauna within a wide range of sizes (e.g., from macro-zooplankton to megafauna classification and counting, morphometric description, and quantification of intra- and interspecific interactions). Then, acquired baseline biological data can be directly related to multiparametric environmental information obtained via the concomitant collection of geochemical and oceanographic data. ${ }^{12,18,51}$

\subsection{Central Role of Optoacoustic Technologies for} Monitoring. High-definition still and video image data (e.g., 2D, 3D, and hyperspectral) and active acoustic imaging (i.e., multibeam cameras ${ }^{52}$ ) to date represent key approaches for the optoacoustic monitoring of remote deep-sea. ${ }^{8}$ Outputs of optoacoustic monitoring provide relevant data for management in key human activities, as for example fisheries or jellyfish blooms. ${ }^{53-56}$ Moreover, species distribution and habitat use can be studied over extended spatial scales by mosaicking highresolution imagery, captured by mobile platforms operating in the regions surrounding the cabled infrastructure stations ${ }^{25}$ or by integrating laser-scanning systems into the mobile platforms, to create high-resolution 3D full-color surface models. ${ }^{57}$ Further development of similar methods that expand the spatial coverage of (stereo)imaging data, can help with the quantification of other biological components and fauna sizes of high ecological relevance which are more difficult to quantify remotely over extensive areas of the deep sea. Fixed cameras ${ }^{11}$ and mobile platforms $^{58}$ can be used to assess epibenthic bacterial mat coverage in combination with customized molecular and chemical microsensors, providing in situ analysis of microbial communities (see section 3.3), a proxy for chemosynthetic production at reducing sites (e.g., cold-seeps and hydrothermal vents $^{25,59}$ ).

Video imaging at depth requires continuous illumination which carries a poorly understood potential for harmful effects on deep-sea fauna. ${ }^{60,61}$ However, digital still time-lapse cameras may collect in situ images with triggered flash illumination, limiting the exposure to light of these perpetually dark deep-sea ecosystems. At the same time, red or infrared lighting, at wavelengths not detectable by deep-sea animals, has been used with some success ${ }^{62}$ but those wavelengths are rapidly attenuated in water and the resulting monochrome images contain much less information than equivalent color images. ${ }^{63}$

Classic high-definition video monitoring approaches are being integrated with novel acoustic imaging systems ${ }^{52,64}$ with an increasing level of complementarity in deep-water areas (Figure 3). Acoustic cameras, such as high-frequency multibeam imaging dual-frequency identification sonar (DIDSON) and adaptive resolution imaging sonar (ARIS) can visualize fish and invertebrate shapes and track the movement of individuals at distances greater than those which may be achieved by visual systems equipped with artificial lighting solutions. ${ }^{65}$

A limitation of acoustic camera use for monitoring fauna however is related to animal identification, which with acoustic systems must be solely based on morphology, since no colorimetric and limited texture information is captured by acoustic camera devices. Spatial resolution of acoustic cameras is also insufficient to resolve important details for species identification. However, acoustic cameras can effectively "see in the dark", thus avoiding photic contamination, allowing investigation of how artificial lights may influence animal 

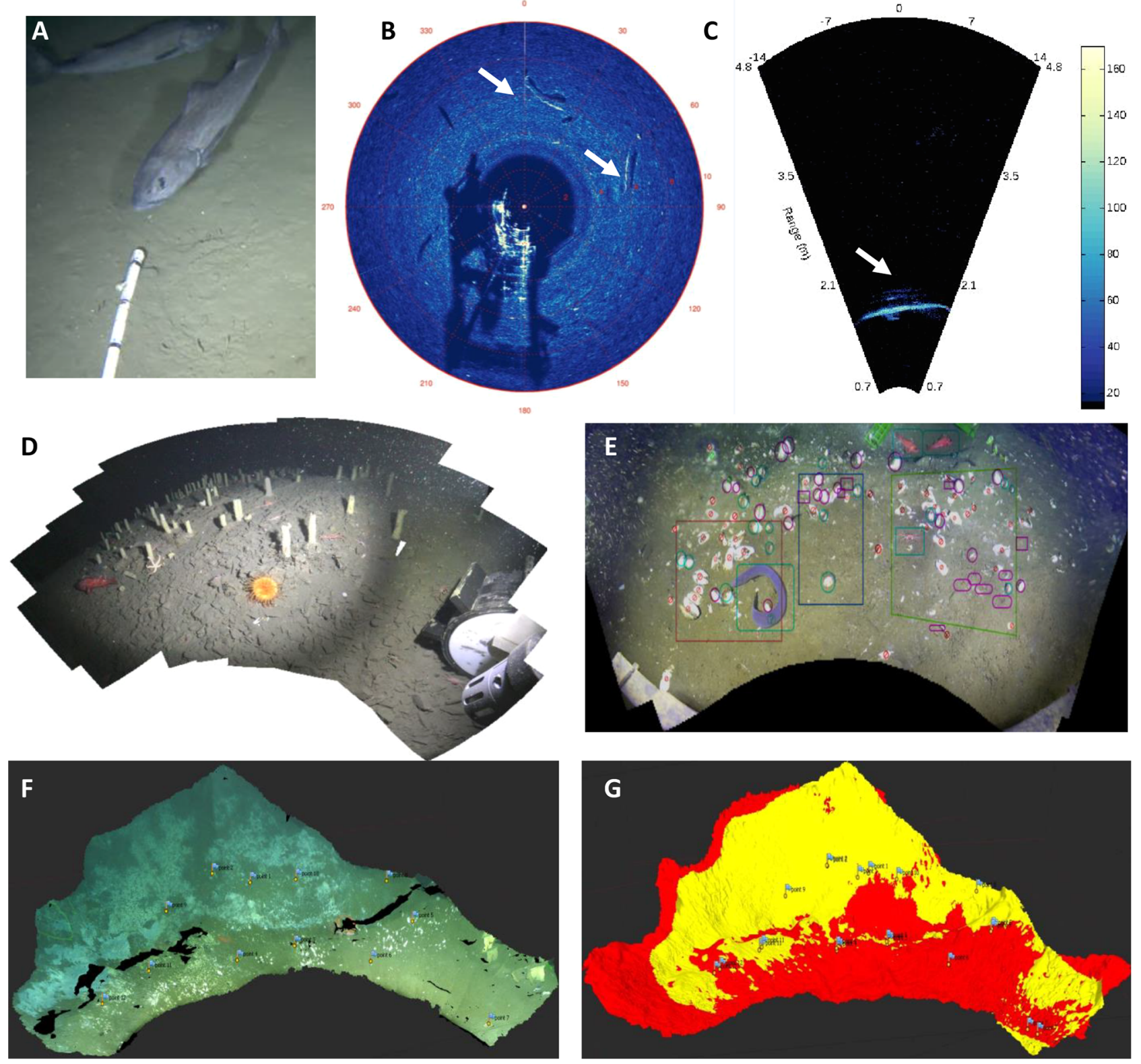

Figure 3. Different video and acoustic imaging data outputs obtained by fixed-point and crawler platforms connected through the Ocean Networks Canada's (ONC) observatory assets in the NE Pacific and Strait of Georgia, Canada. (A, B) Commercially exploited sablefish (Anoplopoma fimbria) imaged from HD video (A) and from an imaging rotary sonar (B), at $970 \mathrm{~m}$ depth in Barkley Canyon; (C) spiny dogfish (Squalus achantias) imaged with an ARIS dual frequency identification sonar at $120 \mathrm{~m}$ depth in the Strait of Georgia [color scale bar indicates raw backscatter reflectivity amplitude (in decibels, dB)]; (D, E) photomosaic by a crawler in Barkley Canyon $(870 \mathrm{~m})$, depicting gastropod' egg towers (D) and a range of benthic species occupying a methane seep habitat patch; (F, G) 3D photomosaics of a methane hydrate mound at the same location, depicting mound area/volume changes over time due to uplift/growth in hydrates (areas in yellow) and slumping (areas in red).

behavior in the deep sea. In order to verify identifications, acoustic cameras must be deployed simultaneously with new prototype low-light high-resolution optical imaging equipment (e.g., $\left.{ }^{66}\right)$.

The space sampled around an observatory can be also increased by mounting an imaging sonar on a rotating head (see Figure 3B). At present such devices are installed on the ONC cabled observatory in Barkley canyon. These sonars allow Internet connected operators to qualitatively discern the presence and abundance of benthic fauna and any associated bioturbation over surfaces larger than in any single fixed image. ${ }^{67}$ Similar rotating side or upward facing sonar packages are undergoing initial deployments on other cabled infrastructures, capable of being used to identify animals, when they are not too densely grouped, at distances of up to $\sim 1 \mathrm{~km}^{68}$

Currently, automation in image processing for animal tracking, classification, counting, the extraction of morphological features (e.g., size, shape, and color patterns), and characterization of behavioral aspects (e.g., crawling, walking, swimming, burying, and territoriality; sensu ref 69) is becoming a relevant tool in biological data provision from cabled observatories and their associated mobile platforms. More automated routines are urgently required as the volume of image data collected by these systems increases in line with technological developments. Such routines will enable researchers to overcome the human analysis-dependent bottleneck of 
manual processing, ${ }^{12}$ while also reducing observer bias. ${ }^{13}$ By developing artificial intelligence ( $\mathrm{AI}$; in the form of learning algorithms) in computer vision, cameras may be transformed into the equivalent of a calibrated sensor, automatically providing time series quantitative data on key fauna, to augment the qualitative data represented by the images themselves. ${ }^{55,56}$ Despite the difficulties inherent in converting the expert knowledge into useful algorithms, calibration and tuning via sufficiently extensive feedback can result in operational performances comparable to those of expert researchers. ${ }^{70}$

3.2. Passive Acoustic Monitoring To Support ImageBased Monitoring. PAM monitoring of fish and invertebrate sounds increase species monitoring capability well beyond the reach of optoacoustic technologies. Such a technological application has become an important tool in fisheries and conservation research. ${ }^{71,72}$ The use of PAM assets provides a long-range monitoring capability in remote locations where traditional sampling methods are difficult or impossible to implement, ${ }^{73}$ such as for example in the case of sponge reefs ${ }^{74}$ or seamounts. ${ }^{75}$ Furthermore, combining acoustic localization with video and other forms of observation can be used to identify sound producing species as well as document their soniferous behavior. ${ }^{76}$ This approach is finding an increasing use in the collection of long-term data for integrated biodiversity assessment. $^{77}$

Unfortunately, the application of PAM is limited by the paucity of archived data on fish sounds. ${ }^{78,79}$ For example, of the approximately 400 fish species in British Columbia waters, only 22 have been reported to "vocalize" in large part because sound production has been investigated in so few species. ${ }^{80}$ This is especially true in the deep sea, where fish sounds have rarely been studied despite the fact that many species possess sonic muscles presumably used in vocalization. ${ }^{81,82}$

Although many fishes and invertebrates do not produce purposeful sounds, it is important to understand that incidental sound production may occur upon physiological and behavioral activity (e.g., specific swimming and feeding mode sounds). Those acoustic marks can be used to assess the presence of individuals for a certain species and are therefore being incorporated into PAM monitoring procedures. ${ }^{71,83}$

The aforementioned PAM applications, combined with other observation technologies (e.g., video, acoustic imaging, and sonar) improving the documentation of organism sound production and associated behavior, will add further ecological value to the integrated monitoring framework of ocean observatories. $^{64}$

3.3. Molecular Sensing as Benchmark for Species Traceability. Molecular tools have diverse applications in marine ecological studies and biological monitoring. Substantial contributions have been provided by several DNA barcode initiatives generating and implementing databases, along with the development of metabarcoding protocols to recover community diversities from unsorted samples. ${ }^{84}$ The latest revolution in biomonitoring is linked to the collection and analysis of genetic material obtained directly from environmental samples, namely, environmental DNA (eDNA). This protocol enables tracing of the presence of species from skin cells, fish scales, gametes, and food leftovers, without the need to isolate any target organisms. ${ }^{85}$ Direct sequencing of eDNA has been shown to provide several advantages over traditional techniques, improving the capacity to unravel the "hidden" biodiversity (e.g., detect rare, cryptic, elusive, and non- indigenous species in the early stages of invasion) and enabling global census of species in near real time. ${ }^{86}$

However, eDNA tracing presents some limitations such as, for example, the detection of false positives (when a target species is absent but its DNA is recovered) and false negatives (i.e., species undetected where they are present) which have to be carefully evaluated and avoided. ${ }^{85,87}$ Major difficulties encountered in deep-sea ecosystems for studies involving molecular analysis of diversity are the general lack of taxonomic knowledge as well as the absence of appropriate databases of species-specific marker sequences. ${ }^{8-90}$ When these molecular markers are identified, ${ }^{91}$ in situ hybridization techniques may be used with great success when targeting expected taxa within monitoring programmes. ${ }^{92,93}$

Recent technical improvements concern the development of "eco-genomic" sensors capable of autonomously collect biological samples and perform molecular analyses. ${ }^{94}$ These sensors allow the characterization of marine community composition as a whole, regardless of the faunal size classes involved. ${ }^{95}$ One example is the environmental sample processor $\left(\mathrm{ESP}^{96}\right)$, designed to autonomously collect discrete water samples, concentrate microorganisms, and automate the application of molecular probe technologies.

In parallel, recent advances in high-throughput sequencing technologies are allowing the processing of huge amounts of genomic data using small portable devices (i.e., miniaturized sequencers such as that produced by Oxford Nanopore Technologies having the size of a USB stick). These kinds of devices, together with advances in bioinformatics, could represent the most important revolutionary breakthrough technology in ecological networks monitoring. Challenges related to the taxonomic assignments of genomic sequences and their interpretation (incompleteness of databases) may be solved by applying machine learning algorithms. ${ }^{97}$ Such approaches can maximize ecologically meaningful insights and provide a list of highly informative sequences ecosystem indicators that could provide the basis for hybridization chips (i.e., microarrays) for denser, more mobile, and cheaper in situ devices that can be scaled up appropriate spatiotemporal resolutions. $^{98}$

AI approaches are gaining relevance in the metabarcoding analysis and provide a fast and cost-effective way for assessing the quality status of ecosystems. ${ }^{98,99}$ Recent examples in omics analysis were based on random forest ${ }^{100,101}$ and self organizing maps. ${ }^{102}$ These were used for identifying biotic indices for the foraminiferal metabarcoding. Similarly, ref 103 used a random forest based approach for selecting the relevant biomarkers for classification of ocean, harbor, and ballast water samples. ${ }^{104}$ used a deep recurrent neural network (approach for a base calling application on portable sequencing machines, ${ }^{105}$ where meaningful results were sent to a cloud service through an Internet of Things framework for further analysis. ${ }^{106}$

Along with molecular-based monitoring tools, other chemical sensing applications may complement DNA probing ${ }^{107}$ and sequencing. An example is provided by in situ mass spectrometry, originally developed for targeting xenobiotic compounds in marine water microsamples, which has been successfully used for identifying species' presence based on their physiological byproducts. ${ }^{108}$

3.4. Ecosystem Indicators. In the near future, the integration of advanced genomic and chemical approaches for in situ detection of organisms ${ }^{97}$ and quantification of their biochemical activity ${ }^{109}$ will greatly enhance the performance of 
ecological monitoring networks, adding to the detection capacity of optoacoustic imaging and passive acoustic approaches alone.

Stitched imaging products (e.g., mosaicking) can provide valuable information on species distribution and habitat use at more extended scales. In situ molecular methods can detect the presence of taxa otherwise undetected by imaging outside a small temporal window or too small for morphological recognition, while acoustics expand the spatial scales of deepsea biological monitoring, enabling the integration of horizontal (nektobenthic displacement ${ }^{69}$ ) and vertical (i.e., benthopelagic coupling ${ }^{34}$ ) biomass and energy fluxes. With the use of such combined data sets, a series of biological variables can be measured and ecosystem indicators extracted, as essential elements for the accurate assessment of the health of benthic ecosystems and cover the complete range from benthic (e.g., chemosynthetic) primary production, individual characteristics, population dynamics, and species and community dynamics to finally the ecosystem functioning level.

As a result of these ever-growing demands, the need for automation in data collection, analysis, and interpretation procedures is paramount. Integration of cabled observatories and associated mobile systems equipped with AI for real-time content extraction from imaging systems, hydrophones, and eDNA samplers, would allow the monitoring of ecosystem indicators and representation of ecosystem functioning over extended spatiotemporal scales (from square meters to kilometers, over days, months, seasons, and decades). To date, no such integrated system exists in the deep sea to verify the concept. ${ }^{8}$ At present there are major shortfalls in automation of image and sound processing and producing an efficient, longterm in situ e-DNA extraction and sequencing device. However, many of these systems are integrated into the ONC cabled observatory infrastructure in the NE Pacific, with data being collected in real time at a number of nodes and returned to a central repository (i.e., Ocean 2.0 data bank system). Similarly, real-time, interactive tools such as the Scripps Plankton Camera System (http://spc.ucsd.edu/) facilitate quick access to visual data and a statistical overview. The implementation of these types of data repositories can allow environmental comparisons to be made among neighboring and more distantly arrayed platforms in an attempt to scale local results over a larger networked area (Figure 4). This endeavor is providing the guidelines for future development of spatiotemporally integrated monitoring protocols.

Autonomous monitoring of biological variables and derived ecosystem indicators by cabled observatories and their integrated mobile platforms should be implemented following a general and standardized common operational protocol: (i) all multiparametric readings from optoacoustic imaging, PAM, molecular, biogeochemical, and oceanographic sensors should be acquired synchronously by all cabled and mobile platforms; (ii) such data acquisition should occur in a high-frequency and time-lapse mode, where the image content should be automatically analyzed by AI algorithms and classified on board of the device (saving storage PAM and transmission bandwidth space), while preserving the observation time georeferenced stamp; and finally; (iii) all mobile platforms should constantly survey the same benthic and pelagic areas (subdivided into specific stations) among cabled observatories and their moored vertical projections. Such an automated and spatiotemporally coordinated and standardized protocol for data acquisition will make data treatment, transmission, and storage easier, while
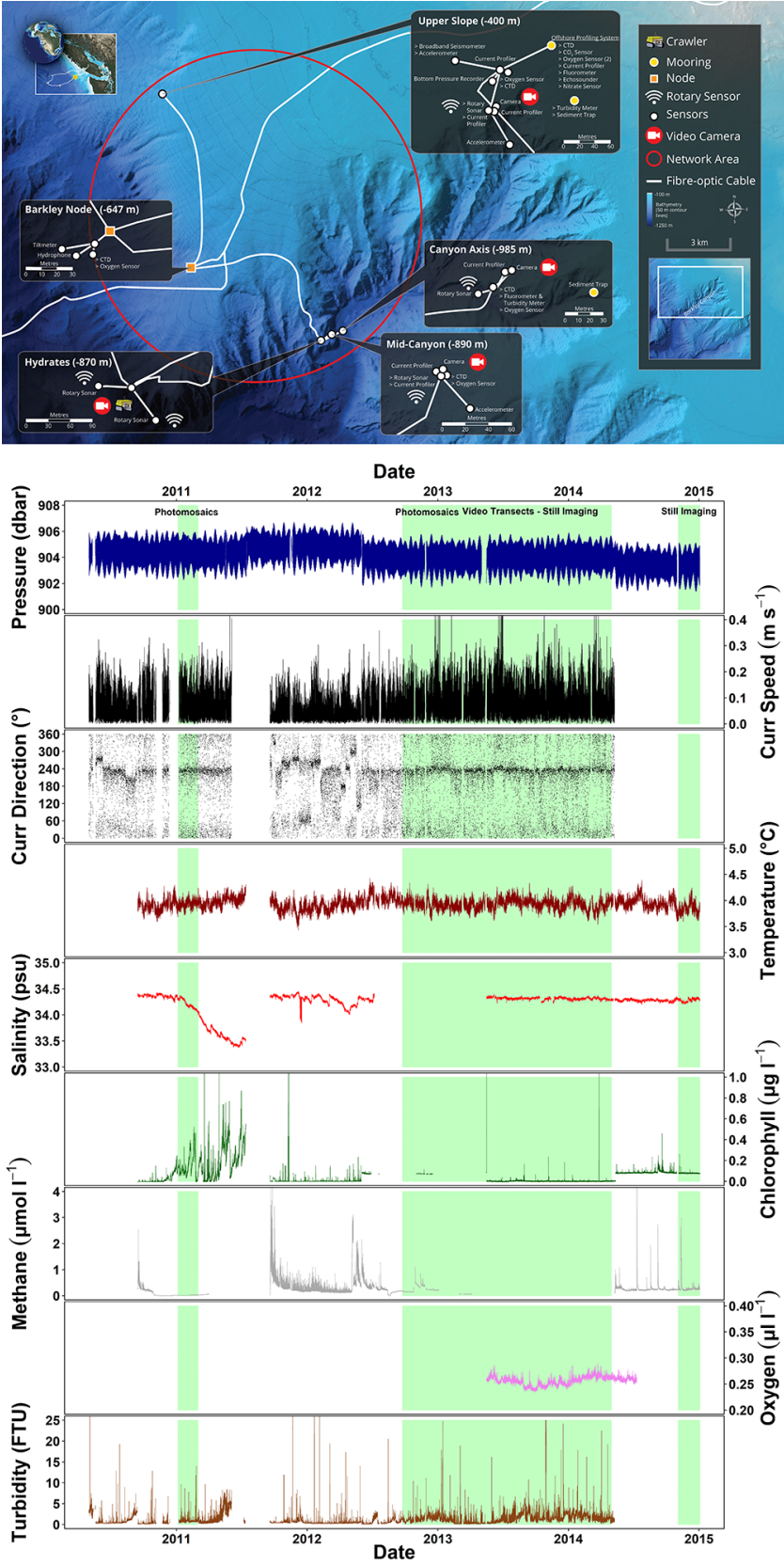

Figure 4. Schematic representation of current seafloor monitoring infrastructure ONC in Barkley Canyon, where a power node distributes energy and data transmission capability to serve fixed multiparametric imaging platforms and a crawler. The mobile platforms communication and coordinated function makes this area the first cooperative network (shown in the red circle) for the deep-sea ecological monitoring. As an example of the power of ongoing multiparametric monitoring, time series from several environmental sensors for the crawler are presented over consecutive years (data plotted at $1 \mathrm{~h}$ frequency). When gaps in data acquisition occur, data can be supplied by nearby cabled platform (as interpolated to cover maintenance periods). Shaded green areas indicate moments at which the environmental monitoring by the crawler has been accompanied by image collection, the processing of which is still manual, while automated scripts for animal tracking and species classification are under development.

simultaneously facilitating more straightforward repeatability/ reproducibility of observations at the same location and comparison of measurements made with other networks, allowing regional/global level analysis. 
Table 2. Indicators Extraction Roadmap: Consecutive Automatable Steps for the Hierarchical Computing of Ecosystem Indicators from Input Biological Variables, Obtained by Bio-imaging and Other Sensing Technologies, Installed on Spatially Distributed Autonomous Networks of Cabled Observatories and Their Connected Mobile Benthic and Pelagic Platforms

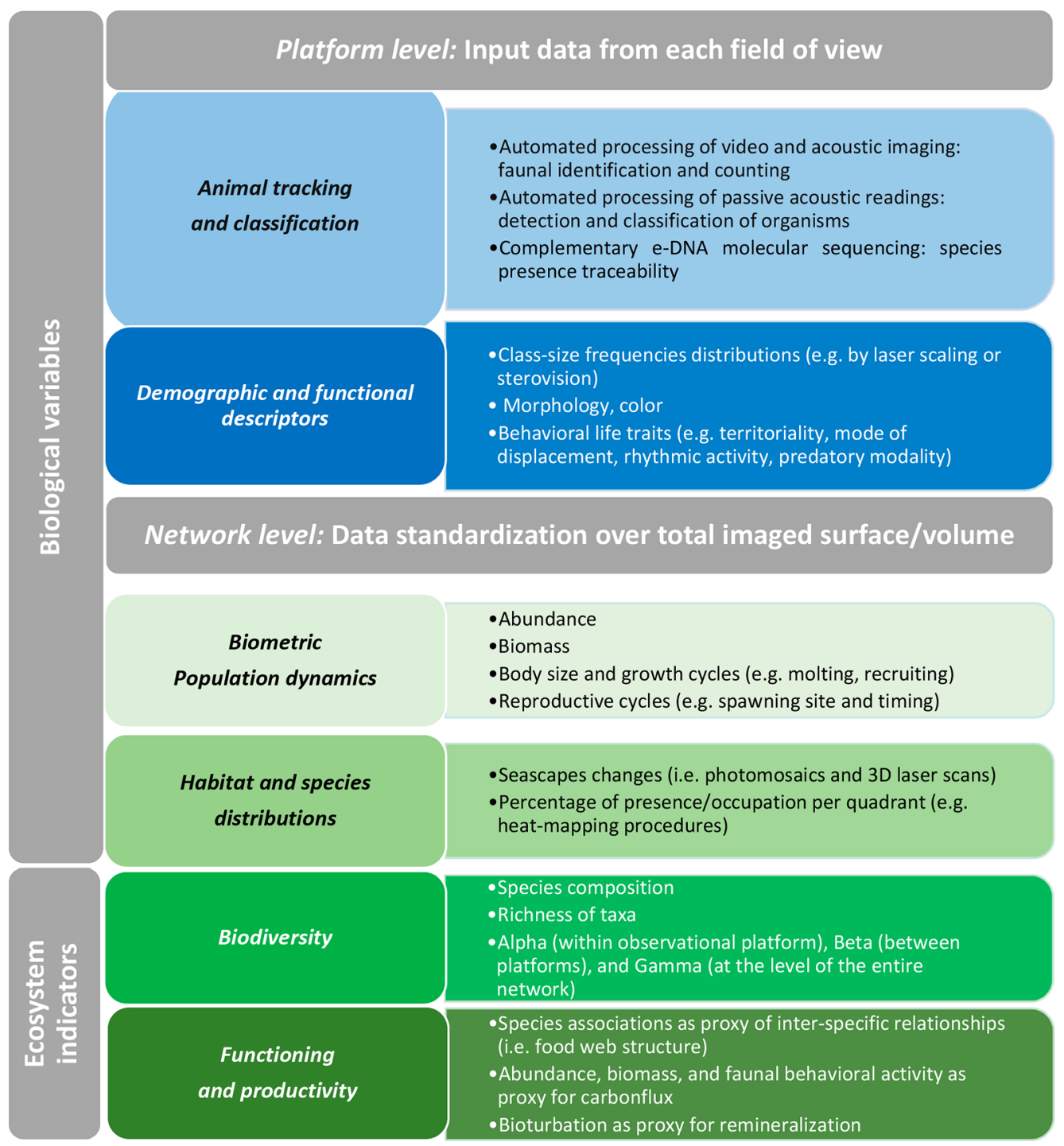

The measurement of biological variables needed for the hierarchical computation of ecosystem indicators, should be carried out through a series of sequential automated steps (Table 2): (i) all imaging outputs initially processed for the classification, counting, and tracking of fauna and quantification of bacterial mat coverage and activity; (ii) animals measured (e.g., by stereovision, acoustic scaling, or laser scanning) to obtain class-size frequency distribution and sex ratio (when morphology allows individual discrimination); (iii) total species counts from all seabed and water-column areas summed and standardized for the imaged volume, to obtain an overall abundance (i.e., density) and biomass estimation; (iv) species counts computed for each station analyzed by mapping procedures (e.g., percentage of presence/occupation per quadrant), to derive information on habitat use as well as displacement routes through different zones (i.e., corridors); (v) a species richness list and biodiversity obtained at each platform ( $\alpha$ diversity), between platforms ( $\beta$ diversity), and the level of the whole network ( $\gamma$ diversity), to assess habitat heterogeneity influences on species distribution, community composition, and overall ecosystem boundaries; finally, (vi) density and biomass for each species related to carbon inputs from benthopelagic fluxes in chlorophyll- $a$ and turbidity (as proxy for transported organic and inorganic matter), as well as from geochemical fluxes, when relevant (i.e., carrying the reduced chemicals, for example methane, hydrogen, and sulfide, that fuel chemosynthetic microbes), to calculate ecosystem functioning and productivity performances. All automated analysis stages need to be verified by human researchers to ensure accuracy of the algorithm functioning, while the nature of specified ecological interpretation must be cross-checked against published results from conventional methods such as analysis of stomach contents, stable isotopes, and fatty acids. ${ }^{110}$

\section{PERSPECTIVES AND OUTLOOK}

Autonomous flexible networks of cabled observatories and mobile platforms can allow extensive monitoring of marine life at different levels of biological organization and at unprecedented spatial and temporal resolution. Although integrated monitoring actions such as those outlined herein are yet to attain full 
operational readiness, and therefore proofs of some of the concepts discussed are missing, the technological developments are ongoing. Progress to date already allows researchers to utilize services-oriented ecological monitoring of some isolated deepsea ecosystems. It is important, however, that future observatories are designed from the ground up for ecosystem monitoring and data integration, rather than being developed on an ad hoc, and somewhat haphazard, basis, as funding for individual projects becomes available.

Bioimaging technologies already play a central role in ecosystem exploration and monitoring. Increasing levels of automation in image processing are transforming cameras into true sensors, delivering time series data for a number of biological variables and derived ecosystem indicators. Visual data are being increasingly complemented by in situ passive acoustic listening sensors and new e-DNA sequencing technologies for species traceability. All these initially disparate data sources can be combined to form a detailed and highresolution monitoring approach applicable to the benthic and pelagic components of a deep-sea ecosystem. The output from such a monitoring regime will support decisions of policy makers, allowing them to assess the impacts of increased industrial activities and pressures on deep-sea ecosystems (e.g., oil or gas extraction and mining or trawl fishing), including a better assessment of already evident but poorly quantified climate change impacts at great depths. The obtained data will be of paramount importance for the accurate assessment of the health status of ecosystems and the physical damage to habitats and for efficient monitoring of their resilience and the efficacy of restoration actions. The compiling of multiannual time series monitoring data sets (continuously updated in real time) will allow the identification of shifting environmental baselines and rapidly highlight the onset of any negative environmental impacts which may develop, potentially unpredictably, from human activities in these remote deep-sea ecosystems.

\section{AUTHOR INFORMATION}

\section{Corresponding Author}

*Phone: +34 9323095 00; fax: +34 9323095 55; e-mail: jaguzzi@icm.csic.es.

\section{ORCID}

\section{Jacopo Aguzzi: 0000-0002-1484-8219}

\section{Notes}

The authors declare no competing financial interest.

\section{ACKNOWLEDGMENTS}

This work was developed within the framework of the Tecnoterra (ICM-CSIC/UPC) and the following project activities: ARIM (Autonomous Robotic sea-floor Infrastructure for benthopelagic Monitoring; MartTERA ERA-Net Cofound), ARCHES (Autonomous Robotic Networks to Help Modern Societies; German Helmholtz Association), RESBIO (Grant TEC2017-87861-R; Ministerio de Ciencia, Innovación y Universidades), RESNEP (Grant CTM2017-82991-C2-1-R; Ministerio de Ciencia, Innovación y Universidades), MERCES (Marine Ecosystem Restoration in Changing European SeasGA No. 689518), and IDEM (Implementing the MSFD to the Deep Mediterranean Sea, GA No. 11.0661/2017/750680/ SUB/ENV.C2). L.T. acknowledges fruitful discussions with Dr. T. Kwasnitschka with respect to Figure 3F,G.

\section{REFERENCES}

(1) Crutzen, P. J.; Steffen, W. How long have we been in the Anthropocene Era? Clim. Change 2003, 61, 251-257.

(2) Halpern, B. S.; Longo, C.; Lowndes, J. S. S.; Best, B. D.; Frazier, M.; Katona, S. K.; Kleisner, K. M.; Rosenberg, A. A.; Scarborough, C.; Selig, E. R. Patterns and emerging trends in global ocean health. PLoS One 2015, 10 (3), e0117863.

(3) Levin, L.; Le Bris, N. The deep ocean under climate change. Science 2015, 350, 766-768.

(4) Ramírez-Llodra, E.; Brandt, A.; Danovaro, R.; De Mol, B.; Escobar, E.; German, C. R.; Levin, L. A.; Martinez Arbizu, P.; Menot, L.; BuhlMortensen, P.; Narayanaswamy, B. E.; Smith, C. R.; Tittensor, D. P.; Tyler, P. A.; Vanreusel, A.; Vecchione, M. Deep, diverse and definitely different: Unique attributes of the world's largest ecosystem. Biogeosciences 2010, 7, 2851-2899.

(5) Mora, C.; Tittensor, D. P.; Adl, S.; Simpson, A. G. B.; Worm, B. How many species are there on Earth and in the ocean? PLoS Biol. 2011, 9, e1001127-8.

(6) Sutton, T.; Clark, M.; Dunn, D. C.; Halpin, P. N.; Rogers, A. D.; Guinotte, J.; Bograd, S. J.; Angel, M. V.; Perez, J. A.; Wishner, K.; Haedrich, R. L.; Lindsay, D. J.; Drazen, J. C.; Vereshchaka, A.; Piatkowski, U.; Morato, T.; Błachowiak-Samołyk, K.; Robison, B. H.; Gjerde, K. M.; Pierrot-Bults, A.; Bernal, P.; Reygondeau, G. 1.; Heino, M. A global biogeographic classification of the mesopelagic zone. Deep Sea Res., Part I 2017, 126, 85-102.

(7) Woodall, L. C.; Andradi-Brown, D. A.; Brierley, A. S.; Clark, M. R.; Connelly, D.; Hall, R. A.; Howell, K. L.; Huvenne, V. A. I.; Linse, K.; Ross, R. E.; Snelgrove, P.; Stefanoudis, P. V.; Sutton, T. T.; Taylor, M.; Thornton, T. F.; Rogers, A. D. A multidisciplinary approach for generating globally consistent data on mesophotic, deep-pelagic, and bathyal biological communities. Oceanography 2018, 31 (3), 76-81.

(8) Danovaro, R.; Aguzzi, J.; Fanelli, E.; Billett, D.; Gjerde, K.; Jamieson, A.; Ramirez-Llodra, E.; Smith, C. R.; Snelgrove, P. V. R.; Thomsen, L.; Van Dover, C. L. An ecosystem-based deep-ocean strategy. Science 2017, 355, 452-454.

(9) Danovaro, R.; Snelgrove, P. V.; Tyler, P. Challenging the paradigms of deep-sea ecology. Trends in Ecology and Evolution 2014, $29,465-475$.

(10) Snelgrove, P V. R.; Soetaert, K.; Solan, M.; Thrush, S.; Wei, C.H.; Danovaro, R.; Fulweiler, R. W.; Kitazato, H.; Ingole, B.; Norkko, A.; Parkes, J. R.; Volkenborn, N. Global carbon cycling on a heterogeneous seafloor. Trends in Ecology and Evolution 2018, 33, 96-105.

(11) Zhao, S.; Ward, J. E.; Danley, M.; Mincer, T. J. Field-based evidence for microplastic in marine aggregates and mussels: Implications for trophic transfer. Environ. Sci. Technol. 2018, 52, 11038-11048.

(12) Aguzzi, J.; Company, J. B.; Costa, C.; Matabos, M.; Azzurro, E.; Mànuel, A.; Menesatti, P.; Sardà, F.; Canals, M.; Delory, E.; Cline, D.; Favali, P.; Juniper, S. K.; Furushima, Y.; Fujiwara, Y.; Chiesa, J. J.; Marotta, L.; Priede, I. M. Challenges to assessment of benthic populations and biodiversity as a result of rhythmic behaviour: Video solutions from cabled observatories. Oceanography and Marine Biology: An Annual Review; CRC Press: Boca Raton, FL, USA, 2012; Vol. 50, pp 235-286, DOI: $10.1201 / \mathrm{b} 12157$.

(13) Schoening, T.; Bergmann, M.; Ontrup, J.; Taylor, J.; Dannheim, J.; Gutt, J.; Purser, A.; Nattkemper, T. W. Semi-automated image analysis for the assessment of megafaunal densities at the Arctic Deepsea observatory Hausgarten. PLoS One 2012, 7, e38179.

(14) Favali, P.; Person, R.; Barnes, C. R.; Kaneda, Y.; Delaney, J. R.; Hsu, S.-K. (2010) Seafloor Observatory Science. Proceedings of the OceanObs'09: Sustained Ocean Observations and Information for Society, Vol. 2, ESA Publication WPP-306, Venice, Italy, Sep. 21-25, 2009; Hall, J., Harrison, D. E., Stammer, D., Eds.; DOI: 10.5270/ OceanObs09.cwp.28.

(15) Favali, P.; Beranzoli, L.; De Santis, A. Seafloor Observatories: A new vision of the earth from the abyss; Springer Science \& Business Media: Berlin, Heidelberg, Germany2015.

(16) Lelièvre, Y.; Legendre, P.; Matabos, M.; Mihaly, S.; Lee, R. W.; Sarradin, P. M.; Arango, C. P.; Sarrazin, J. Astronomical and 
atmospheric impacts on deep-sea hydrothermal vent invertebrates. Proc. R. Soc. London, Ser. B 2017, 284, 20162123.

(17) Ruhl, H. A.; André, M.; Beranzoli, L.; Çağatay, N. M.; Colaço, A.; Cannat, M.; Dañobeitia, J. J.; Favali, P.; Géli, L.; Gillooly, M.; Greinert, J.; Hall, P. O. J.; Huber, R.; Karstensen, J.; Lampitt, R. S.; Larkin, K. E.; Lykousis, V.; Mienert, J.; Miguel Miranda, J. M. A.; Person, R.; Priede, I. G.; Puillat, I.; Thomsen, L.; Waldmann, C. Societal need for improved understanding of climate change, anthropogenic impacts, and geohazard warning drive development of ocean observatories in European Seas. Prog. Oceanogr. 2011, 91 (1), 1-33.

(18) Aguzzi, J.; Doya, C.; Tecchio, S.; De Leo, F. 1.; Azzurro, E.; Costa, C.; Sbragaglia, V.; Del Río, J.; Navarro, J.; Ruhl, H. A.; Company, J. B.; Favali, P.; Purser, A.; Thomsen, L.; Catalán, I. A. Coastal observatories for monitoring of fish behavior and their responses to environmental changes. Review of Fish Biology and Fisheries 2015, 25, 463-483.

(19) Barnes, C. R.; Best, M. M. R.; Bornhold, B. D.; Juniper, S. K.; Pirenne, B.; Phibbs, P. The NEPTUNE Project - A cabled ocean observatory in the NE Pacific: Overview, challenges and scientific objectives for the installation and operation of Stage I in Canadian waters. IEEE Underwater Technology and Workshop on Scientific Use of Submarine Cables and Related Technologies, Apr. 17-20, 2007, Tokyo, Japan; IEEE: New York, 2007; DOI: 10.1109/UT.2007.370809.

(20) Vardaro, M. F.; Bagley, P. M.; Bailey, D. M.; Bett, B. J.; Jones, D. O. B.; Milligan, R. J.; Priede, I. G.; Risien, C. M.; Rowe, G. T.; Ruhl, H. A.; Sangolay, B. B.; Smith, K. L., Jr.; Walls, A.; Clarke, J. A Southeast Atlantic deep-ocean observatory: First experiences and results. Limnol. Oceanogr.: Methods 2013, 11, 304-315.

(21) Bagley, P. M.; Smith, K. L.; Bett, B. J.; Priede, I. G.; Rower, G. T.; Clarke, J.; Wall, A.; Ruhl, A. H.; Bailey, D. M.; Bazica, B. The DELOS project: Development of a long-term observatory in an oil field environment in the Tropical Atlantic Ocean. In Seafloor Observatories. Favali, P., et al., Eds.; Springer Praxis Books Series; Springer: Berlin, Heidelberg, 2015; 10.1007/978-3-642-11374-1 13.

(22) Osterloff, J.; Nilssen, I.; Nattkemper, T. $\bar{W}$. A computer vision approach for monitoring the spatial and temporal shrimp distribution at the LoVe observatory. Methods Oceanogr. 2016, 15-16, 114-128.

(23) Doya, C.; Chatzievangelou, D.; Bahamon, N.; Purser, A.; De Leo, F.; Juniper, K.; Thomsen, L.; Aguzzi, J. Seasonal monitoring of deep-sea cold-seep benthic communities using an Internet Operated Vehicle (IOV). PLoS One 2017, 12, e0176917.

(24) Thomsen, L.; Aguzzi, J.; Costa, C.; De Leo, F.; Ogston, A.; Purser, A. The oceanic biological pump: Rapid carbon transfer to depth at Continental Margins during winter. Sci. Rep. 2017, 7, 10763.

(25) Purser, A.; Thomsen, L.; Barnes, C.; Best, M.; Chapman, R.; Hofbauer, M.; Menzel, M.; Wagner, H. Temporal and spatial benthic data collection via Internet operated Deep Sea Crawler. Methods in Oceanography 2013, 5, 1-18.

(26) Flögel, S. A new concept for high resolution benthic mapping and data acquisition: MANSIO-VIATOR. Presented at the AGU Fall Meeting, San Francisco, CA, USA, 2015.

(27) Bellingham, J. G. Autonomous Underwater Vehicle Docking. In Springer Handbook of Ocean Engineering; Dhanak, M. R., Xiros, N. I., Eds.; Springer: Cham, Switzerland, 2016; DOI: 10.1007/978-3-31916649-0 16.

(28) Ludvigsen, M.; Sørensen, A. J. Towards integrated autonomous underwater operations for ocean mapping and monitoring. Annual Reviews in Control 2016, 42, 145-157.

(29) Masmitja, I.; Gomariz, S.; Del Rio, J.; Kieft, B.; O’Reilly, T.; Bouvet, P. J.; Aguzzi, J. Optimal path shape for range-only underwater target localization using a Wave Glider. International Journal of Robotics Resrearch 2018, 37 (12), 1447-1462.

(30) Morris, K. J.; Bett, B. J.; Durden, J. M.; Huvenne, V. A. I.; Milligan, R.; Jones, D. O. B.; McPhail, S.; Robert, K.; Bailey, D. M.; Ruhl, H. A. A new method for ecological surveying of the abyss using autonomous underwater vehicle photography. Limnol. Oceanogr.: Methods 2014, 12, 795-809.

(31) Williams, S. B.; Pizarro, O.; Steinberg, D. M.; Friedman, A.; Bryson, M. Reflections on a decade of autonomous underwater vehicles operations for marine survey at the Australian Centre for Field Robotics. Annual Reviews in Control 2016, 42, 158-165.

(32) Robison, B. H.; Reisenbichler, K. R.; Sherlock, R. E. The coevolution of midwater research and ROV technology at MBARI. Oceanography 2017, 30, 26-37.

(33) Rountree, R. A.; Juanes, F. First attempt to use a remotely operated vehicle to observe soniferous fish behavior in the Gulf of Maine, Western Atlantic Ocean. Curr. Zool. 2010, 56 (1), 90-99.

(34) Griffiths, J. R.; Kadin, M.; Nascimento, F. J. A.; Tamelander, T.; Tornroos, A.; Bonaglia, S.; Bonsdorff, E.; Bruchert, V.; Gardmark, A.; Jarnstrom, M.; Kotta, J.; Lindegren, M.; Nordstrom, M. C.; Norkko, A.; Olsson, J.; Weigel, B.; Zydelis, R.; Blenckner, T.; Niiranen, S.; Winder, $M$. The importance of benthic-pelagic coupling for marine ecosystem functioning in a changing world. Glob. Change Biol. 2017, 23, 21792196.

(35) Adrián-Martínez, S.; The NEMO Consortium; Aiello, S.; Ameli, F.; et al. Long-term monitoring of the optical background in the Capo Passero deep-sea site with the NEMO tower prototype. Eur. Phys. J. C 2016, 76, 68 .

(36) Adrián-Martínez, S.; The NEMO Consortium; Ageron, M.; Aharonian, F.; et al. The prototype detection unit of the KM3NeT detector. Eur. Phys. J. C 2016, 76, 54.

(37) Nosengo, N.; Riccobene, G.; Pavan, G. The neutrino and the whale. Nature 2009, 462, 560-561.

(38) Sciacca, V.; Caruso, F.; Beranzoli, L.; Chierici, F.; De Domenico, E.; Embriaco, D.; Favali, P.; Giovanetti, G.; Larosa, G.; Marinaro, G.; Papale, E.; Pavan, G.; Pellegrino, C.; Pulvirenti, S.; Simeone, F.; Viola, S.; Riccobene, G. Annual acoustic presence of fin whale (Balaenoptera physalus) offshore eastern Sicily, Central Mediterranean Sea. PLoS One 2015, 10, e0141838.

(39) Viola, S.; Grammauta, R.; Sciacca, V.; Bellia, G.; Beranzoli, L.; Buscaino, G.; Caruso, F.; Chierici, F.; Cuttone, G.; D’Amico, A.; De Luca, V.; Embriaco, D.; Favali, P.; Giovanetti, G.; Marinaro, G.; Mazzola, S.; Filiciotto, F.; Pavan, G.; Pellegrino, C.; Pulvirenti, S.; Simeone, F.; Speziale, F.; Riccobene, G. Continuous monitoring of noise levels in the Gulf of Catania (Ionian Sea): Study of correlation with ship traffic. Mar. Pollut. Bull. 2017, 121, 97-103.

(40) Aguzzi, J.; Fanelli, E.; Ciuffardi, T.; Craig, G.; the NEMO Consortium; Schirone, A. Inertial bioluminescence rhythms at the Capo Passero (Km3NeT-Italia) site, Central Mediterranean. Sci. Rep. 2017, 7, 44938.

(41) Tamburini, C.; The ANTARES Consortium; Canals, M.; Durrieu de Madron, X.; et al. Deep-sea bioluminescence blooms after dense water formation at the ocean surface. PLoS One 2013, 8, e67523.

(42) Durrieu de Madron, X.; Ramondenc, S.; Berline, L.; Houpert, L.; Bosse, A.; Martini, S.; Guidi, L.; Conan, P.; Curtil, C.; Delsaut, N.; Kunesch, S.; Ghiglione, J. F.; Marsaleix, P.; Pujo-Pay, M.; Séverin, T.; Testor, P.; Tamburini, C. Deep sediment resuspension and thick nepheloid layer generation by open-ocean convection. Journal of Geophysical Research and Oceanography 2017, 122, 2291-2318.

(43) Aguzzi, J.; Jamieson, A. J.; Fujii, T.; Sbragaglia, V.; Costa, C.; Menesatti, P.; Fujiwara, Y. Shifting feeding behaviour of deep-sea buccinid gastropods at natural and simulated food falls. Mar. Ecol.: Prog. Ser. 2012, 458, 247-253.

(44) Aguzzi, J.; Costa, C.; Robert, K.; Matabos, M.; Antonucci, F.; Juniper, S. K.; Menesatti, P. Automated image analysis for the detection of benthic crustaceans and bacterial mat coverage using the VENUS undersea cabled network. Sensors 2011, 11, 10534-10556.

(45) Aguzzi, J.; Fanelli, E.; Ciuffardi, T.; Schirone, A.; De Leo, F. C.; Doya, C.; Kawato, M.; Miyazaki, M.; Furushima, Y.; Costa, C.; Fujiwara, Y. Faunal activity rhythms influencing early community succession of an implanted whale carcass offshore in Sagami Bay, Japan. Sci. Rep. 2018, 8, 11163.

(46) Borcard, D.; Legendre, P. All-scale spatial analysis of ecological data by means of principal coordinates of neighbour matrices. Ecol. Modell. 2002, 153 (1-2), 51-68.

(47) Matabos, M.; Bui, A. O. V.; Mihály, S.; Aguzzi, J.; Juniper, S. K.; Ajayamohan, R. S. High-frequency study of epibenthic megafaunal community dynamics in Barkley Canyon: A multi-disciplinary 
approach using the NEPTUNE Canada network. Journal of Marine Systems 2014, 130, 56-68.

(48) Puillat, I.; Prevosto, M.; Mercier, H.; Thomas, S. Time series analysis of marine data: a key knowledge at the crossroads of marine sciences. Journal of Marine Systems 2014, 130, 1-3.

(49) Allen, T. F. H. Hierarchy Theory in Ecology. In Ecosystem ecology; Jorgensen, S. E., Ed.; Elsevier: Amsterdam, The Netherlands, 2009.

(50) Danovaro, R.; Carugati, L.; Berzano, M.; Cahill, A. E.; Carvalho, S.; Chenuil, A.; Corinaldesi, C.; Cristina, S.; David, R.; Dell'Anno, A.; Dzhembekova, N.; Garcés, E.; Gasol, J. M.; Goela, P.; Féral, J.-P.; Ferrera, I.; Forster, R. M.; Kurekin, A. A.; Rastelli, E.; Marinova, V.; Miller, P. I.; Moncheva, S.; Newton, A.; Pearman, J. K.; Pitois, S. G.; Reñé, A.; Rodríguez-Ezpeleta, N.; Saggiomo, V.; Simis, S. G. H.; Stefanova, K.; Wilson, C.; Lo Martire, M.; Greco, S.; Cochrane, S. K. J.; Mangoni, O.; Borja, A. Implementing and innovating marine monitoring approaches for assessing marine environmental status. Front. Mar. Sci. 2016, 3, 213.

(51) Ferrari, R.; Bryson, M.; Bridge, T.; Hustache, J.; Williams, S. B.; Byrne, M.; Figueira, W. Quantifying the response of structural complexity and community composition to environmental change in marine communities. Global Change Biology 2016, 22, 1965-1975.

(52) Juanes, F. Visual and acoustic sensors for early detection of biological invasions: Current uses and future potential. Journal of Nature Conservation 2018, 42, 7-11.

(53) Samhouri, J. F.; Haupt, A. J.; Levin, P. S.; Link, J.; Shuford, R. Lessons learned from developing integrated ecosystem assessments to inform marine ecosystem-based management in the USA. ICES J. Mar. Sci. 2014, 71, 1205-1215.

(54) Bicknell, A. W.; Godley, B. J.; Sheehan, E. V.; Votier, S. C.; Witt, M. J. Camera technology for monitoring marine biodiversity and human impact. Front. Ecol. Environ. 2016, 14 (8), 424-432.

(55) Corgnati, L.; Marini, S.; Mazzei, L.; Ottaviani, E.; Aliani, S.; Conversi, A.; Griffa, A. Looking inside the Ocean: Toward an autonomous imaging system for monitoring gelatinous zooplankton. Sensors 2016, 16, 2124.

(56) Marini, S.; Corgnati, L.; Mantovani, C.; Bastianini, M.; Ottaviani, E.; Fanelli, E.; Aguzzi, J.; Griffa, A.; Poulain, P. M. Automated estimate of fish abundance through the autonomous imaging device GUARD1. Measurement 2018, 126, 72-75.

(57) GE Reports Canada. Autonomous undersea robots are using lasers to make offshore operations safer and more efficient. 2017 Retrieved from https://krakenrobotics.com/autonomous-undersearobots-using-lasers-make-offshore-operations-safer-efficient/.

(58) Valentine, D. L.; Fisher, G. B.; Pizarro, O.; Kaiser, C. L.; Yoerger, R. D.; Breier, J. A.; Tarn, J. Autonomous Marine Robotic Technology Reveals an Expansive Benthic Bacterial Community Relevant to Regional Nitrogen Biogeochemistry. Environ. Sci. Technol. 2016, 50, $11057-11065$.

(59) Russ, L.; Kartal, B.; Op Den Camp, H. J. M.; Sollai, M.; Le Bruchec, J.; Caprais, J. C.; Godfroy, A.; Sinninghe Damsté, J. S.; Jetten, M. S. M. Presence and diversity of anammox bacteria in cold hydrocarbon-rich seeps and hydrothermal vent sediments of the Guaymas Basin. Front. Microbiol. 2013, 4, 219.

(60) Herring, P. J.; Gaten, E.; Shelton, P. M. J. Are vent shrimps blinded by science? Nature 1999, 398, 116-116.

(61) Irwin, A. The dark side of light: How artificial lighting is harming the natural world. Nature 2018, 553, 268-270.

(62) Widder, E. A.; Robison, B. H.; Reisenbichler, K. R.; Haddock, S. H. D. Using red light for in situ observations of Deep-sea fishes. Deep Sea Res., Part I 2005, 52, 2077-2085.

(63) Priede, I. G. Deep-sea fishes: Biology, diversity, ecology and fisheries. Cambridge University Press: Cambridge, U.K., 2017.

(64) Rountree, R. Do you hear what I hear? Future technological development and needs in passive acoustics underwater observation. Mar. Technol. Rep. 2008, 51 (9), 40-46.

(65) Martignac, F.; Daroux, A.; Bagliniere, J.-L.; Ombredane, D.; Guillard, J. The use of acoustic cameras in shallow waters: New hydroacoustic tools for monitoring migratory fish population. A review of DIDSON technology. Fish Fish. 2015, 16, 486-510.
(66) Barbier, R.; Cajgfinger, T.; Dominjon, A.; Doan, Q. T. An ebCMOS camera system for extreme low light imaging. Presented at Imaging Systems and Applications 2012; Optical Society of America: Monterey, CA, USA, 2012; DOI: 10.1364/ISA.2012.ITu4C.6.

(67) Robert, K.; Juniper, S. K. Surface-sediment bioturbation quantified with cameras on the NEPTUNE Canada cabled observatory. Mar. Ecol.: Prog. Ser. 2012, 453, 137-149.

(68) Godø, O. R.; Handegard, N. O.; Browman, H.; Macaulay, G. J.; Kaartvedt, S.; Giske, J. O. E.; Huse, G.; Johnsen, E.; Ona, E. Marine Ecosystem Acoustics (MEA): Quantifying processes in the sea at the spatio-temporal scales on which they occur. ICES J. Mar. Sci. 2014, 71, 2357-2369.

(69) Aguzzi, J.; Company, J. B. Chronobiology of deep-water decapod crustaceans on continental margins. Adv. Mar. Biol. 2010, 58, 155-225.

(70) MacLeod, N.; Benfield, M.; Culverhouse, P. Time to automate identification. Nature 2010, 467, 154-155.

(71) Rountree, R.; Gilmore, R.; Goudey, C.; Hawkins, A.; Luczkovich, J.; Mann, D. Listening to fish: Applications of passive acoustics to fisheries science. Fisheries 2006, 31 (9), 433-446.

(72) Luczkovich, J.; Mann, D.; Rountree, R. Passive Acoustics as a Tool in Fisheries: An Introduction to the American Fisheries Society Symposium. Trans. Am. Fish. Soc. 2008, 137, 533-541.

(73) Alliance for Coastal Technologies (ACT) Underwater passive acoustic monitoring for remote regions. A workshop of research scientists, technology developers, and resource managers, Hawaii Institute of Marine Biology, Coconut Island, HI, USA, Feb. 7-9, 2007, Ref. No. ACT0702; ACT: Solomons, MD, USA, 2007.

(74) Archer, S. K.; Halliday, W. D.; Riera, A.; Mouy, X.; Pine, M. K.; Chu, J. W. F.; Dunham, A.; Juanes, F. The first description of a glass sponge reef soundscape reveals fish calls and elevated sound pressure levels. Mar. Ecol.: Prog. Ser. 2018, 595, 245-252.

(75) Riera, A.; Rountree, R.; Mouy, X.; Ford, J. K.; Juanes, F. Effects of anthropogenic noise on fishes at the SGaan Kinghlas-Bowie Seamount Marine Protected Area. Proc. Meet. Acoust. 2016, 27, No. 010005.

(76) Mouy, X.; Rountree, R.; Juanes, F.; Dosso, S. E. Cataloging fish sounds in the wild using combined acoustic and video recordings. $J$. Acoust. Soc. Am. 2018, 143, EL333-EL339.

(77) Pieretti, N.; Lo Martire, M.; Farina, A.; Danovaro, R. Marine soundscape as an additional biodiversity monitoring tool: A case study from the Adriatic Sea (Mediterranean Sea). Ecol. Indic. 2017, 83, 1320.

(78) Rountree, R. A.; Perkins, P. J.; Kenney, R. D.; Hinga, K. R. Sounds of Western North Atlantic fishes: Data rescue. Bioacoustics 2002, 12 (2-3), 242-244.

(79) Rountree, R. A.; Bolgan, M.; Juanes, F. How can we understand freshwater soundscapes without fish sound descriptions? Fisheries 2019, 44, 137-143.

(80) Wall, C.; Rountree, R.; Pomerleau, C.; Juanes, F. An exploration of deep-sea fish sounds off Vancouver Island from the NEPTUNE Canada ocean observing system. Deep Sea Res., Part I 2014, 83, 57-64.

(81) Rountree, R.; Juanes, F.; Goudey, C.; Elkstrom, K. Is biological sound production important in the deep sea? In The effects of noise on aquatic life; Popper, A. N., Hawkins, A., Eds.; Springer Science and Business Media: New York, NY, USA, 2012; DOI: 10.1007/978-14419-7311-5 41.

(82) Parmentier, E.; Bahri, M. A.; Plenevaux, A.; Fine, M. L.; Estrada, J. M. Sound production and sonic apparatus in deep-living cusk-eels (Genypterus chilensis and Genypterus maculatus). Deep Sea Res., Part I 2018, 141, 83-92.

(83) Rountree, R. A.; Juanes, F.; Bolgan, M. Air movement sound production by alewife, white sucker, and four salmonid fishes suggests the phenomenon is widespread among freshwater fishes. PLoS One 2018, 13 (9), e0204247.

(84) Stefanni, S.; Stanković, D.; Borme, D.; de Olazabal, A.; Pallavicini, A.; Tirelli, V.; Juretić. Multi-marker metabarcoding approach to study mesozooplankton at basin scale. Sci. Rep. 2018, 8, 12085.

(85) Taberlet, P.; Coissac, E.; Hajibabaei, M.; Rieseberg, L. H. Environmental DNA. Mol. Ecol. 2012, 21, 1789-1793. 
(86) Stat, M.; Huggett, M. J.; Bernasconi, R.; DiBattista, J. B.; Berry, T. E.; Newman, S. J.; Harvey, E. S.; Bunce, M. Ecosystem biomonitoring with eDNA: Metabarcoding across the tree of life in a tropical marine environment. Sci. Rep. 2017, 7, 12240.

(87) Cristescu, M. E.; Hebert, P. D. N. Uses and Misuses of Environmental DNA in Biodiversity Science and Conservation. Annual Review of Ecology, Evolution, and Systematics 2018, 49, 209-230.

(88) Carugati, L.; Corinaldesi, C.; Dell'Anno, A.; Danovaro, R. Metagenetic tools for the census of marine meiofaunal biodiversity: An overview. Marine Genomics 2015, 24 (1), 11-20.

(89) Dell'Anno, A.; Carugati, L.; Corinaldesi, C.; Riccioni, G.; Danovaro, R. Unveiling the biodiversity of deep-sea nematodes through metabarcoding: Are we ready to bypass the classical taxonomy? PLoS One 2015, 10, e0144928.

(90) Sinniger, F.; Pawlowski, J.; Harii, S.; Gooday, A.; Yamamoto, H.; Chevaldonne, P.; Cedhagen, T.; Carvalho, G.; Creer, S. Worldwide analysis of sedimentary DNA reveals major gaps in taxonomic knowledge of Deep-sea benthos. Front. Mar. Sci. 2016, 3, 92.

(91) Barnes, M. A.; Turner, C. R. The ecology of environmental DNA and implications for conservation genetics. Conserv. Genet. 2016, 17 (1), 1-17.

(92) Scholin, C. A. What are ecogenomic sensors? A review and thoughts for the future. Ocean Sci. 2010, 6, 51-60.

(93) Berry, T. E.; Saunders, B. J.; Coghlan, M. L.; Stat, M.; Jarman, S.; Richardson, A. J.; Davies, C. H.; Berry, O.; Harvey, E. S.; Bunce, M. Marine environmental DNA biomonitoring reveals seasonal patterns in biodiversity and identifies ecosystem responses to anomalous climatic events. PLoS Genet. 2019, 15, e1007943.

(94) Ottesen, E. A. Probing the living ocean with ecogenomic sensors. Curr. Opin. Microbiol. 2016, 31, 132-139.

(95) McQuillan, J. S.; Robidart, J. C. Molecular-biological sensing in aquatic environments: recent developments and emerging capabilities. Curr. Opin. Biotechnol. 2017, 45, 43-50.

(96) Scholin, C.; Doucette, G.; Jensen, S.; Roman, B.; Pargett, D.; Marin, R., III; Preston, C.; Jones, W.; Feldman, J.; Everlove, C.; Harris, A.; Alvarado, N.; Massion, E.; Birch, J.; Greenfield, D.; Vrijenhoek, R.; Mikulski, C.; Jones, K.; Wheeler, K. Remote detection of marine microbes, small invertebrates, harmful algae, and biotoxins using the Environmental Sample Processor (ESP). Oceanography 2009, 22, 158167.

(97) Cordier, T.; Esling, P.; Lejzerowicz, F.; Visco, J.; Ouadahi, A.; Martins, C.; Cedhagen, T.; Pawlowski, J. Predicting the ecological quality status of marine environments from eDNA metabarcoding data using supervised machine learning. Environ. Sci. Technol. 2017, 51, 9118-9126.

(98) Cordier, T.; Forster, D.; Dufresne, Y.; Martins, C. I.; Stoeck, T.; Pawlowski, J. Supervised machine learning outperforms taxonomybased environmental DNA metabarcoding applied to biomonitoring. Mol. Ecol. Resour. 2018, 18 (6), 1381-1391.

(99) Cordier, T.; Lanzén, A.; Apothéloz-Perret-Gentil, L.; Stoeck, T.; Pawlowski, J. Embracing environmental genomics and machine learning for routine biomonitoring. Trends Microbiol. 2019, 27 (5), 387-397.

(100) Breiman, L. Random forests. Machine Learning 2001, 45 (1), 532.

(101) Fernández-Delgado, M.; Sirsat, M. S.; Cernadas, E.; Alawadi, S.; Barro, S.; Febrero-Bande, M. An extensive experimental survey of regression methods. Neural Networks 2019, 111, 11-34.

(102) Kamimura, R. SOM-based information maximization to improve and interpret multi-layered neural networks: From information reduction to information augmentation approach to create new information. Expert Systems with Applications 2019, 125, 397-411.

(103) Gerhard, W. A.; Gunsch, C. K. Metabarcoding and machine learning analysis of environmental DNA in ballast water arriving to hub ports. Environ. Int. 2019, 124, 312-319.

(104) LeCun, Y.; Bengio, Y.; Hinton, G. Deep learning. Nature 2015, 521 (7553), 436-444.

(105) Merelli, I.; Morganti, L.; Corni, E.; Pellegrino, C.; Cesini, D.; Roverelli, L.; Zereik, G.; D’Agostino, D. Low-power portable devices for metagenomics analysis: Fog computing makes bioinformatics ready for the Internet of Things. Future Generation Computer Systems 2018, $88,467-478$.

(106) Čolaković, A.; Hadžialić, M. Internet of Things (IoT): A review of enabling technologies, challenges, and open research issues. Computer Networks 2018, 144, 17-39.

(107) Ishida, H.; Wada, Y.; Matsukura, H. Chemical sensing in robotic applications: A review. IEEE Sens. J. 2012, 12, 3163-3173.

(108) Wollschlager, J.; Voß, D.; Zielinski, O.; Petersen, W. In situ observations of biological and environmental parameters by means of optics: Development of next-generation ocean sensors with special focus on an Integrating Cavity Approach. IEEE J. Oceanic Eng. 2016, 41, 753-762.

(109) Goodridge, B. M.; Valentine, D. L. Microscale measurement and visualization of sulfide $\delta 34 \mathrm{~S}$ using photographic film sulfide capture coupled with laser ablation multicollector inductively coupled plasma mass spectrometry. Anal. Chem. 2016, 88 (20), 10126-10133.

(110) Choy, C. A.; Haddock, S. H. D.; Robison, B. H. Deep pelagic food web structure as revealed by in situ feeding observations. Proc. $R$. Soc. London, Ser. B 2017, 284 (1868), 20172116.

(111) Aguzzi, J.; Costa, C.; Fujiwara, Y.; Iwase, R.; Ramírez-Llorda, E.; Menesatti, P. A novel morphometry-based protocol of automated video-image analysis for species recognition and activity rhythms monitoring in deep-sea fauna. Sensors 2009, 9, 8438-8455.

(112) Aguzzi, J.; Costa, C.; Furushima, Y.; Chiesa, J. J.; Company, J. B.; Menesatti, P.; Iwase, R.; Fujiwara, Y. Behavioral rhythms of hydrocarbon seep fauna in relation to internal tides. Mar. Ecol.: Prog. Ser. 2010, 418, 47-56.

(113) De Leo, F. C.; Ogata, B.; Sastri, A. R.; Heesemann, M.; Mihály, S.; Galbraith, M.; Morley, M. G. High-frequency observations from a deep-sea cabled observatory reveal seasonal overwintering of Neocalanus spp. in Barkley Canyon, NE Pacific: Insights into particulate organic carbon flux. Prog. Oceanogr. 2018, 169, 120-137.

(114) Ross, T.; Keister, J. E.; Lara-López, A. On the use of highfrequency broadband sonar to classify biological scattering layers from a cabled observatory in Saanich Inlet, British Columbia. Methods in Oceanography 2013, 5, 19-38.

(115) Oswald, J. N.; Au, W. W. L.; Duennebier, F. Minke whale (Balaenoptera acutorostrata) boings detected at the Station ALOHA Cabled Observatory. J. Acoust. Soc. Am. 2011, 129 (5), 3353-3360.

(116) André, M.; The NEMO Consortium; Caballé, A.; van der Schaar, M.; et al. Sperm whale long-range echolocation sounds revealed by ANTARES, a deep-sea neutrino telescope. Sci. Rep. 2017, 7, 45517.

(117) Ryan, J.; Cline, D.; Dawe, C.; McGill, P.; Zhang, Y.; Joseph, J.; Margolina, T.; Caillat, M.; Fischer, M.; DeVogelaere, A.; Stimpert, A.; Southall, B. New Passive Acoustic Monitoring in Monterey Bay National Marine Sanctuary. Proceedings of OCEANS 2016 MTS/IEEE, Monterey, CA, USA, Sep. 19-23, 2016; IEEE: New York, NY, USA, 2016; DOI: 10.1109/OCEANS.2016.7761363.

(118) Caruso, F.; Sciacca, V.; Bellia, G.; De Domenico, E.; Larosa, G.; Papale, E.; Pellegrino, C.; Pulvirenti, S.; Riccobene, G.; Simeone, F.; Speziale, F.; Viola, S.; Pavan, G. Size distribution of sperm whales acoustically identified during long term deep-sea monitoring in the Ionian Sea. PLoS One 2015, 10 (12), e0144503.

(119) Caruso, F.; Alonge, G.; Bellia, G.; De Domenico, E.; Grammauta, R.; Larosa, G.; Mazzola, S.; Riccobene, G.; Pavan, G.; Papale, E.; Pellegrino, C.; Pulvirenti, S.; Sciacca, V.; Simeone, F.; Speziale, F.; Viola, S.; Buscaino, G. Long-term monitoring of dolphin biosonar activity in deep pelagic waters of the Mediterranean Sea. Sci. Rep. 2017, 7, 4321.

(120) Weirathmueller, M. J.; Stafford, K. M.; Wilcock, W. S. D.; Hilmo, R. S.; Dziak, R. P.; Tréhu, A. M. Spatial and temporal trends in fin whale vocalizations recorded in the NE Pacific Ocean between 2003-2013. PLoS One 2017, 12 (10), e0186127.

(121) Weirathmueller, M. J.; Wilcock, W. S. D.; Hilmo, R. S. Estimating range to a vocalizing fin whale using the timing and amplitude of multipath arrivals. J. Acoust. Soc. Am. 2017, 142 (4), $2101-2120$ 
(122) Kanes, K.; Dosso, S. E.; Lado, T. I.; Mouy, X. Automated classification of Pacific white-sided dolphin (Lagenorhynchus obliquidens) pulsed calls for diel pattern assessment. J. Acoust. Soc. Am. 2017, 141 (5), 3941.

(123) Chauvet, P.; Metaxas, A.; Hay, A. E.; Matabos, M. Annual and seasonal dynamics of deep-sea megafaunal epibenthic communities in Barkley Canyon (British Columbia, Canada): A response to climatology, surface productivity and benthic boundary layer variation. Prog. Oceanogr. 2018, 169, 89-105.

(124) Doya, C.; Aguzzi, J.; Pardo, M.; Matabos, M.; Company, J. B.; Costa, C.; Mihály, S.; Canals, M. Diel behavioral rhythms in sablefish (Anoplopoma fimbria) and other benthic species, as recorded by the Deep-sea cabled observatories in Barkley canyon (NEPTUNECanada). Journal of Marine Systems 2014, 130, 69-78.

(125) Cuvelier, D.; Legendre, P.; Laes, A.; Sarradin, P. M.; Sarrazin, J. Rhythms and community dynamics of a hydrothermal tubeworm assemblage at Main Endeavour field - A multidisciplinary deep-sea observatory approach. PLoS One 2014, 9 (5), e96924.

(126) Cuvelier, D.; Legendre, P.; Laes-Huon, A.; Sarradin, P. M.; Sarrazin, J. Biological and environmental rhythms in (dark) deep-sea hydrothermal ecosystems. Biogeosciences 2017, 14, 2955-2977.

(127) Chatzievangelou, D.; Doya, C.; Thomsen, L.; Purser, A.; Aguzzi, $\mathrm{J}$. High-frequency patterns in the abundance of benthic species near a cold-seep: An Internet Operated Vehicle application. PLoS One 2016, 11, $\mathrm{e} 0163808$.

(128) Anderson, G. S.; Bell, L. S. Impact of marine submergence and season on faunal colonization and decomposition of pig carcasses in the Salish Sea. PLoS One 2016, 11 (3), e0149107.

(129) Anderson, G. S.; Bell, L. S. Deep coastal marine taphonomy: Investigation into carcass decomposition in the Saanich Inlet, British Columbia using a baited camera. PLoS One 2014, 9 (10), e110710.

(130) Doya, C.; Aguzzi, J.; Chatzievangelou, D.; Costa, C.; Company, J. B.; Tunnicliffe, V. The seasonal use of small-scale space by benthic species in a transiently hypoxic area. Journal of Marine Systems 2016, $154,280-290$.

(131) Matabos, M.; Aguzzi, J.; Robert, K.; Costa, C.; Menesatti, P.; Company, J. B.; Juniper, S. K. Multi-parametric study of behavioural modulation in demersal decapods at the VENUS cabled observatory in Saanich Inlet, British Columbia, Canada. J. Exp. Mar. Biol. Ecol. 2011, 401, 89-96.

(132) Matabos, M.; Piechaud, N.; De Montigny, F.; Sarradin, P. M.; Sarrazin, J. The VENUS cabled observatory as a method to observe fish behaviour and species assemblages in a hypoxic fjord, Saanich Inlet (British Columbia, Canada). Can. J. Fish. Aquat. Sci. 2015, 72 (1), 2436.

(133) Fujikura, K.; Amaki, K.; Barry, J. P.; Fujiwara, Y.; Furushima, Y.; Iwase, R.; Yamamoto, H.; Maruyama, T. Long-term in situ monitoring of spawning behavior and fecundity in Calyptogena spp. Mar. Ecol:: Prog. Ser. 2007, 333, 185-193.

(134) Juniper, S. K.; Matabos, M.; Mihály, S.; Ajayamohan, R. S.; Gervais, F.; Bui, A. O. V. A year in Barkley Canyon: A time-series observatory study of mid-slope benthos and habitat dynamics using the NEPTUNE Canada network. Deep Sea Res., Part II 2013, 92, 114-123.

(135) Chatzievangelou, D.; Suarez, A., Aguzzi, J.; Bigham, K.; Thomsen, L. Optimization of surveys with Internet operated deep-sea crawler, as an integrated tool for ocean cabled observatories: Monitoring the benthic community of a methane hydrates site in Barkley Canyon (BC, Canada). Presented at the AGU Fall Meeting, Dec. 11-15, 2017, New Orleans, LA, USA.

(136) Matabos, M.; Tunnicliffe, V.; Juniper, S. K.; Dean, C. A Year in Hypoxia: Epibenthic community responses to severe oxygen deficit at a subsea observatory in a coastal inlet. PLoS One 2012, 7 (9), e45626. 